\title{
ضمان الجودة في التعليم الجامعي - دراسة تحليلية اجتهاعية -
}

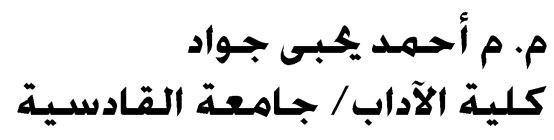

هقدمة:

تسير التوجهات العالمية بخطوات حثيثة نحو زيادة إنتاجية الجامعات وتهيئة فرص النمو الاقتصادي داخلها، من خلال العمل في مشاريع بحثية إنتاجيه والمشاركة في التطوير التقني، والانفتاح على المجتمع وتكوين علاقات متبادلة مع المؤسسات

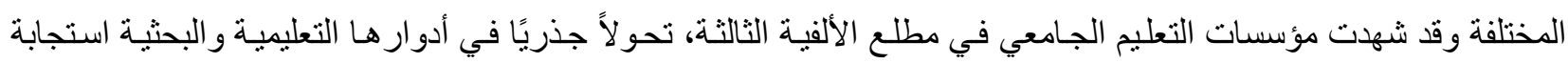

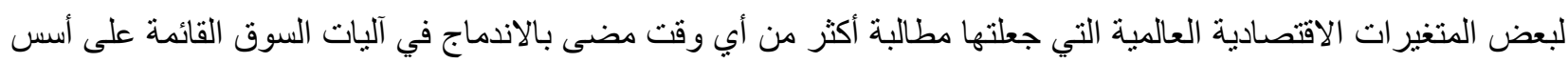

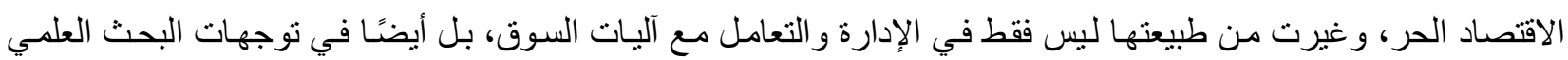

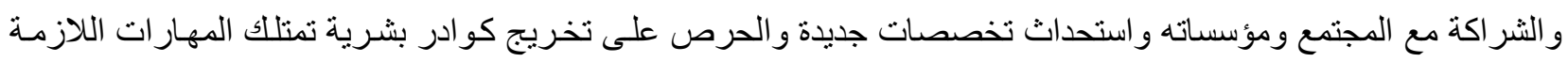

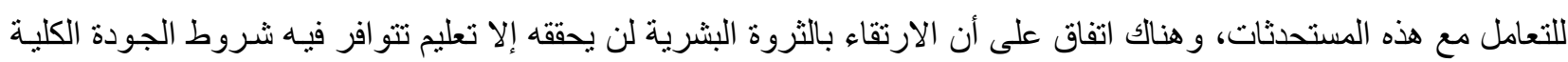

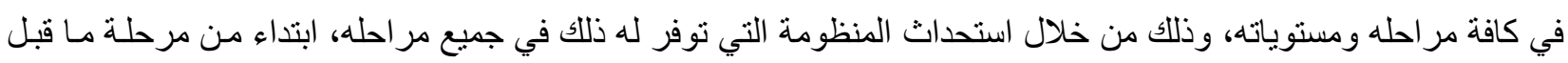

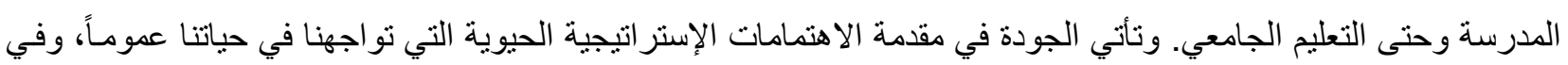

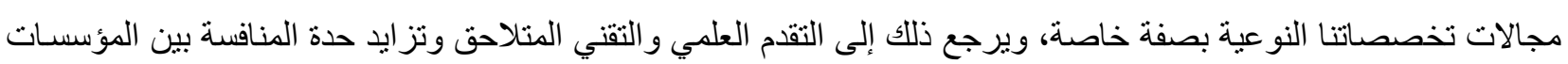
الإنتاجية والخدمية في ظل زيادة العرض عن الطلب. ويتجاوز مفهوم الجودة معناه التقليدي أي جودة المنتج أو الخدمـة ليشتمل

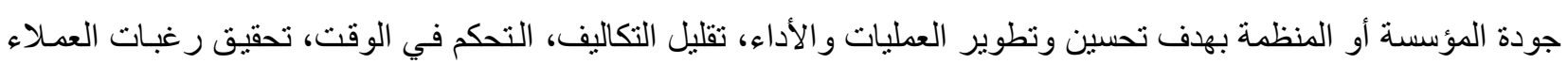
ومتطلبات السوق، العمل بروح الفريق، وتقوية الانتماء.

\section{المبـث الأول: الإطار النظري للدوراسة}

أولاً : موضوع الاراسة:

إن المعرفة العلمية وتوظيفها في مختلف مجالات إلحياة شيء ضروري لألي مجتمع بتطلع للتقام بالمفهوم الثامل. فما

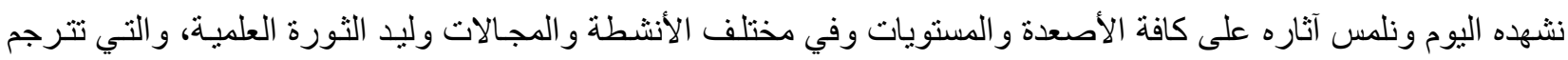

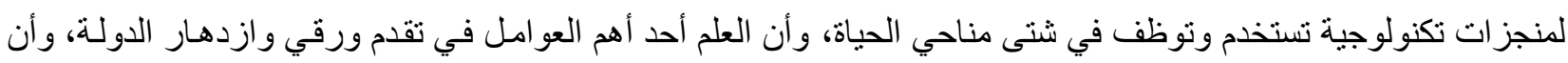

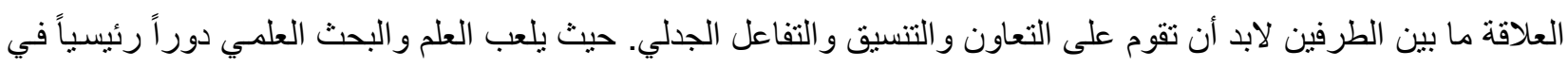

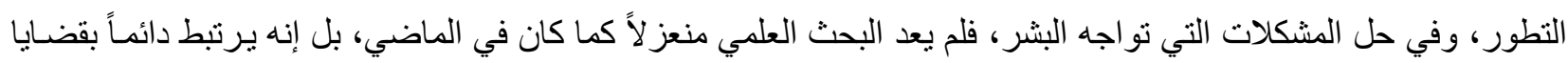

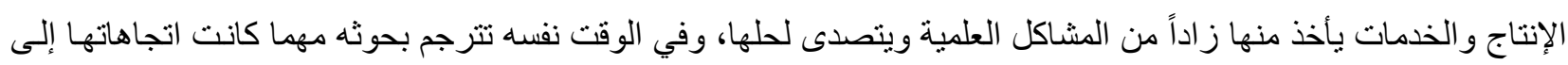

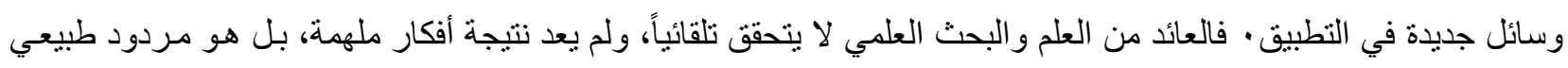

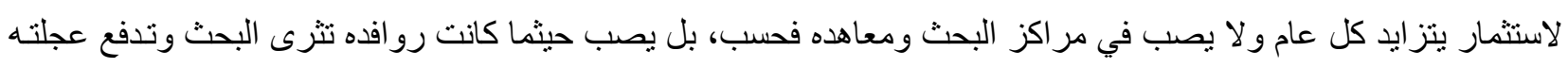

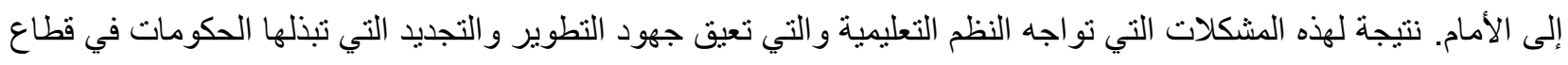

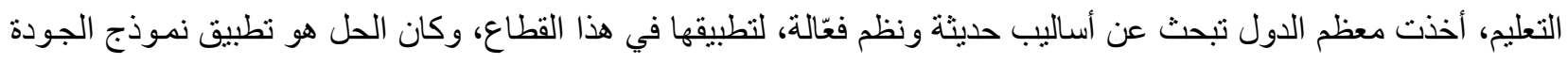

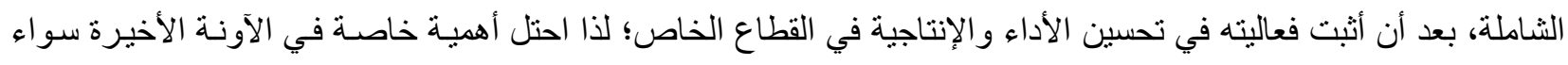

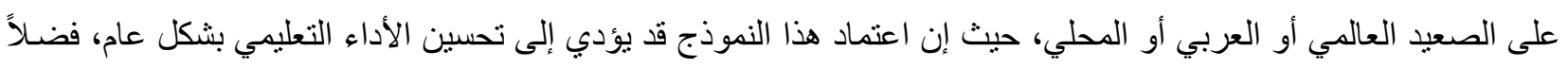

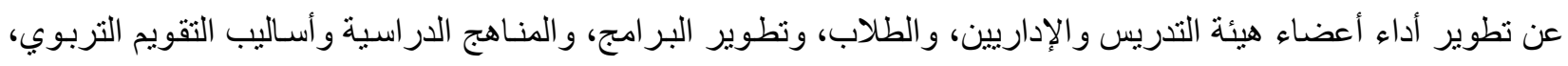

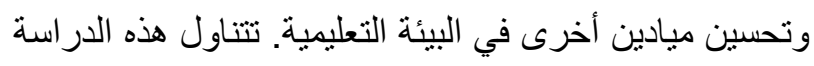


ثانياً: أهداف الدراسة وتساؤلاتها

من خلال التحديد السابق لإشكالية الدراسة، يتركز الهدف الرئيسي في: ـ تحديد أهم السبل التي تعمل على الارتقاء بنظام الجودة الاداء في الجامعات العر اقية. ويندرج تحت هذا الهدف الرئيسي مجموعة الأهداف الفرعية الآتية: ا ـ مناقثة مفهوم الجودة الثاملة في التعليم و التعرف على الرؤى الفكرية المختلفة التي تتاولته. rـ تحديد معايير الجودة في التعليم من وجهة نظر اعضاء هيئة التدريس في الدامعات العراقية. ولتحقيق الأهداف السابقة تسعى الدراسة للإجابة على التساؤل الرئيسي الأتي: ـ ما أهم السبل التي تعمل على الارتقاء بنظام الجودة الاداء في الجامعات العراقية ؟ ويندرج تحت هذا التساؤل الرئيسي مجموعة من التساؤلات الفرعية الآتبة و المرتبطة بالأهداف الفرعية السابقة.

$$
\begin{aligned}
& \text { 1 - ما مفهوم الجودة في التعليم ؟ } \\
& \text { r- ما معايير الجودة في التعليج ؟ }
\end{aligned}
$$

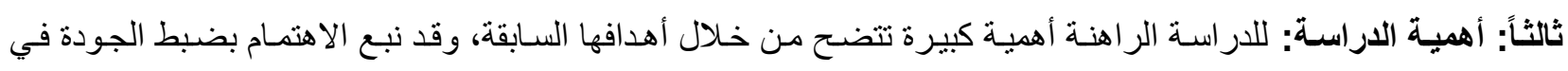

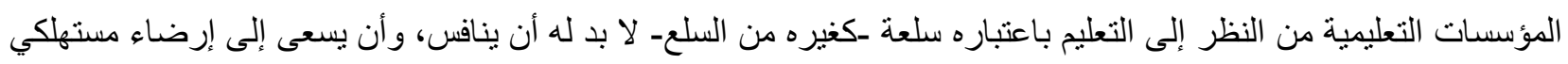

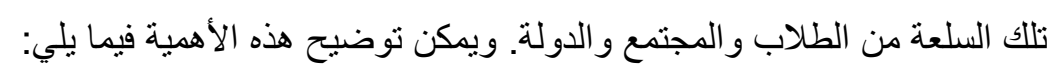
اـ الأهميـة النظريـة: نكمن أهميـة هذه الدراسـة من الناحيـة النظريـة في أنها تنساهم فى وضـع إطـار عن الجامعة ودور هـا

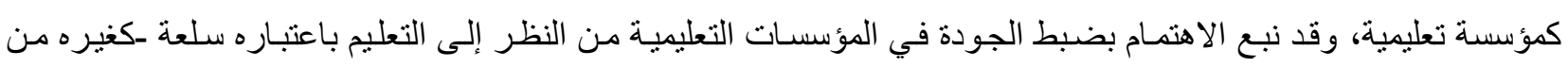
السلع- لا بد له أن ينافس، وأن يسعى إلى إرضاء مستهلكي تللك السلعة من الطلاب و المجتمع و الدولة. rـ الأهمية التطبيقية: ترجع أهميـة هذه الدراسـة من الناحيـة التطبيقيـة إلى التوصل لنتائج قد تكون مفيدة في مجال تطوير

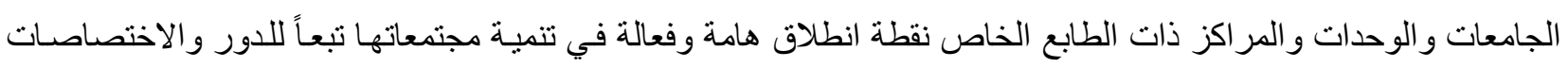

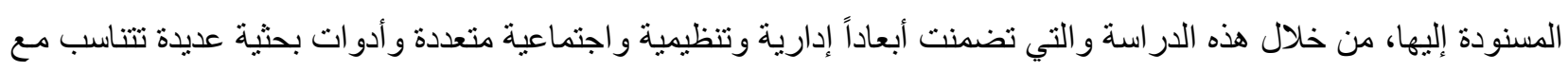
تللك الأدوار و الاختصاصات في سبيل تحقيق الجودة في التعليم الجامعي. rـ الأهمية المستقبلية: تمثل أهمية الدر اسة من الناحية المستقبلية في كونها تعتبر در اسـة قبلية لما يليها من دراسـات مستقبلية

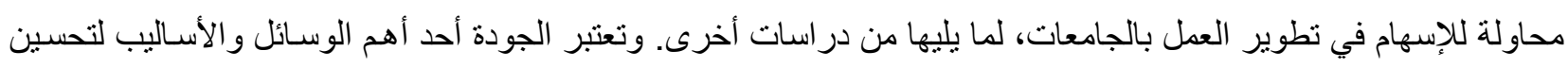

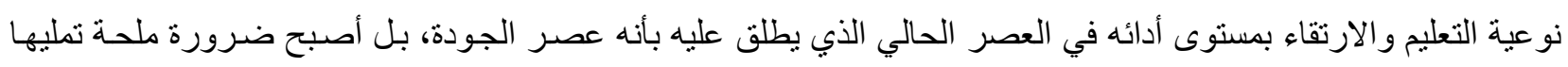
حركة الحياة المعاصرة، وهي دليل على بقاء الروح وروح البقاء لدى المؤسسة التعليمية. رابعاً: تحديا مفاهيم الاراسة اـ الجامعة: كلمة جامعة كلمة مشتقة عربياً من كلمة الاجتماع أي الاجتماع حول هدف وهو هدف هدف التعليم و المعرفة. و الجامعة

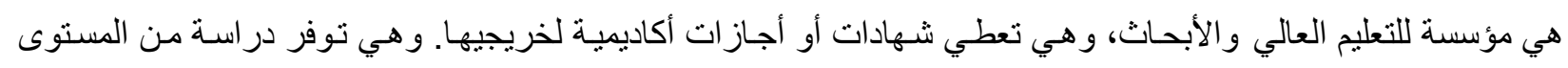

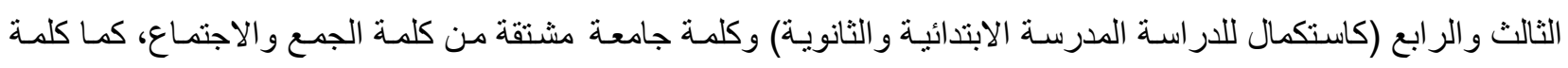

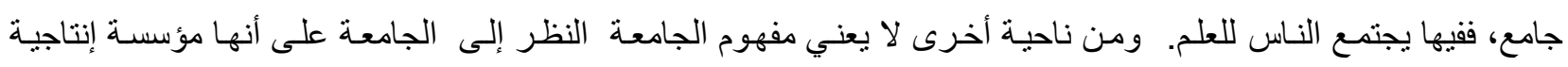


تتصـرف كثـركة تجاريـة، فلجامعـة أهداف تختلف عن تلك التي تسعى الثـركات التجاريـة إلى تحقيقها ، و المهـة الأساسية للجامعة هي التعليم و البحث العلمي وخدمة المجتمع وهي مهمة يجب أن تصان بعيدًا عن المفهوم التجاري التقليدي. ץ- مفهوم الجودة: الجودة في اللغة العربية ضد الرداءة وهي الجيد من كل شيء، يقال جاد: جودة وأجاد: أتى بالجيد من

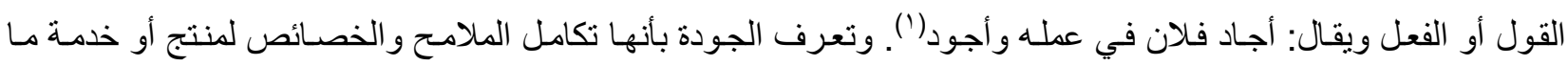
بصورة تمكن من تلبية احتياجات ومتطلبات محددة أو معروفه ضمنا، أو هي مجمو عة من الخصائص و المميزات لكيان ما تعبر عن قدرتها على تحقيق المتطلبات المحددة أو المتوقعة من قبل المستفيد(؟). זـ مفهوم الجودة في التعليم: ويعرف جيبس Gibbs الجودة في التعليم بأنها: كل مـا يؤدي إلى تطوير القدرات الفكريـة و الخيالية عند الطلاب، وتحسين مستوى الفهم والاستيعاب لايهم، ومهار اتهم في حل المشكلات و القضايا، وقدرنهم على تمثل المعلومات بشكل فعال، و النظر في الأمور من خلال ما تعلموه في الماضي وما يدرسونه حالياًّ).

\section{المبمث الثاني: البهودة في التعليم البامعب..} أولاً: ضمان جودة مخرجات التعليم العالي في تلبية احتياجات المجتمع العراقي

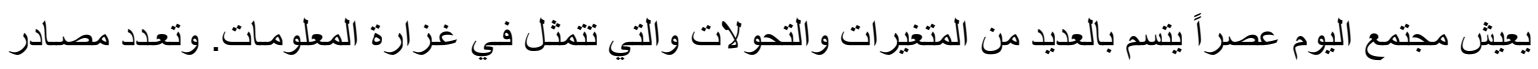

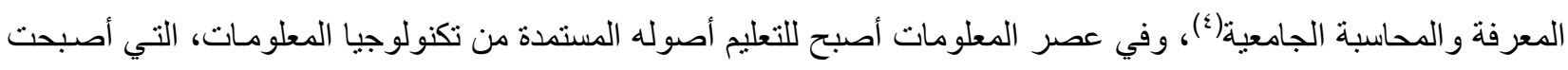

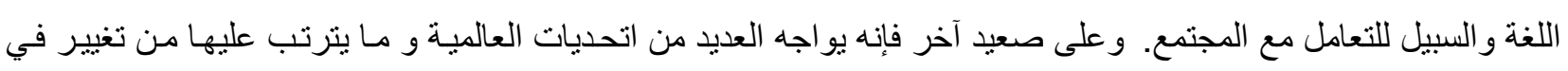

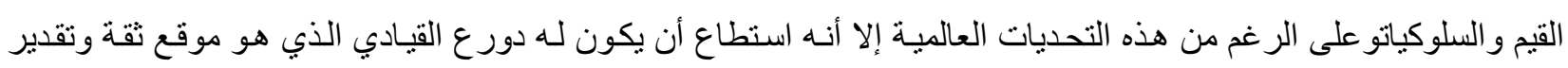

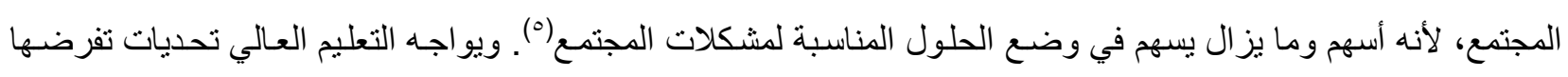

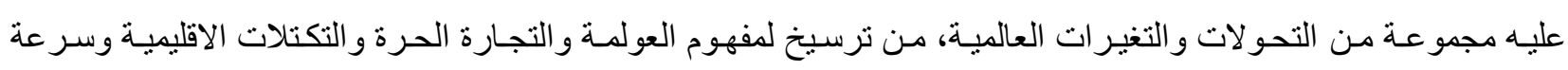

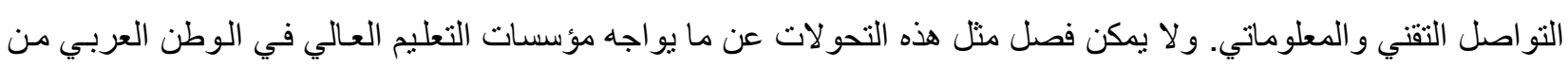
تحديات تتصل بالزيادات المخيفة في نسب بطالة الخريجين و التوجه نحو الخصخصنة ولانئ وانحسار دور القطاع الحكومي، وتدني مساهمة قطاع الإنتاج في شؤون التعليم العالي (ج). هنالك اجتماع حول دور و أهمية التعليم العالي في تلبية منطلبات سوق العمل العر اقي، وهنـا لابد أن تكون مخرجات

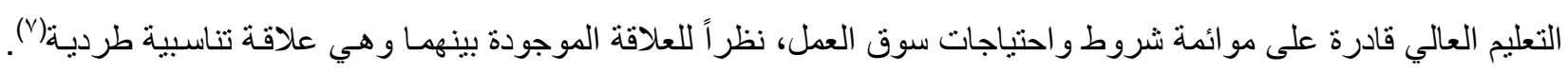

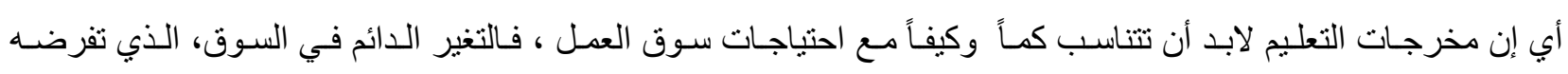

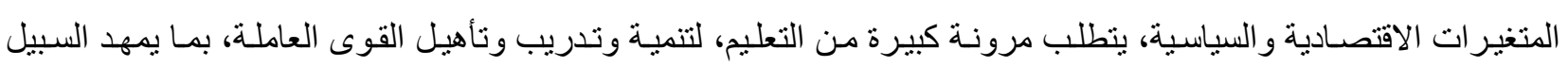

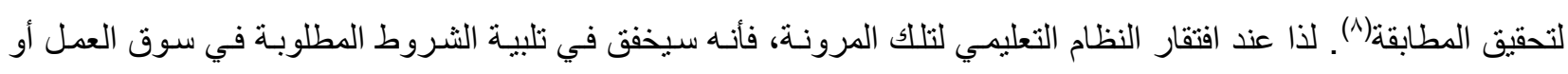

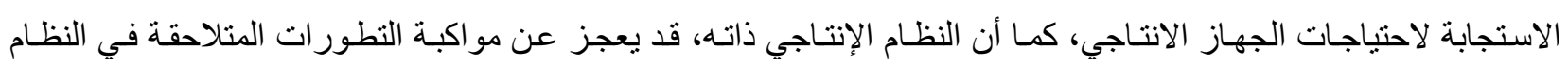

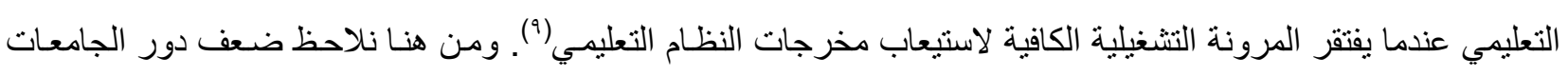

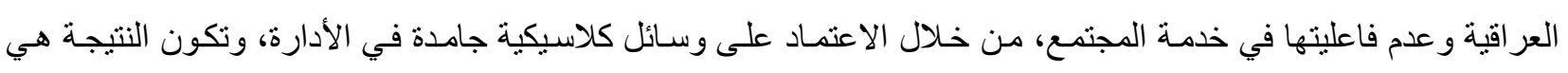

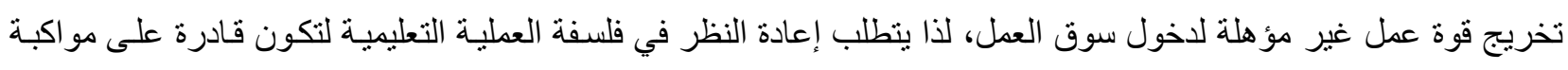

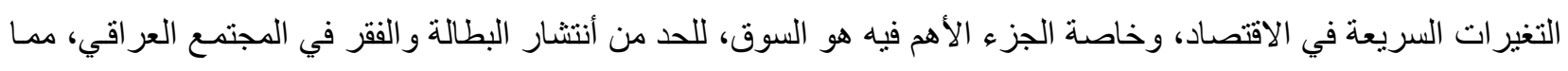

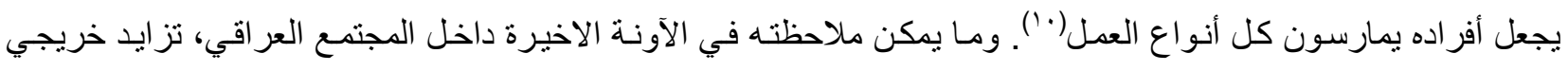

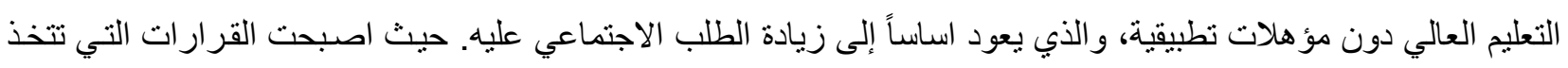

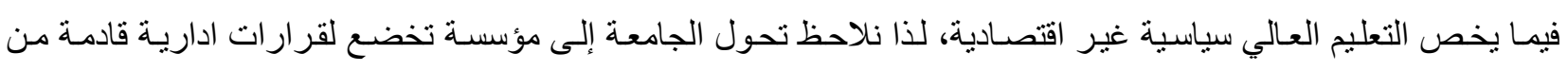


الوزارة بدون تدخل رؤسـاء الجامعة أو المعاهد وطرح وجهت نظرهم أو رؤيتهم للواقع من خلال الاحتكالك بـــ(المجتمع).

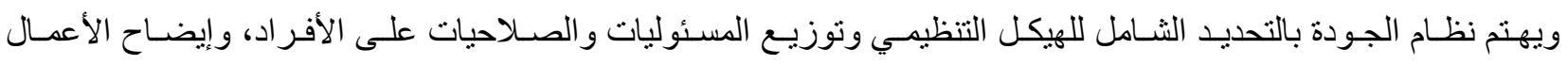
و الإجر اءات الكفيلة بمر اقبة العمل ومتابعته، كذلك مر اقبة وفحص كل ما يرد إلى المؤسسة التعليمية والتأكد على أن الخدمة قد التد تم فحصها و أنها تحقق مستلزمات الجودة المطلوبة. بمر فئل ثانياً: الجودة الثاملة والتعليم الجامعي ان للتعليم الجامعي دور في إعداد منطلبات سوق العمل وكافة الجهات الاجتماعية الداخلية والخارجية وتوفير الموارد

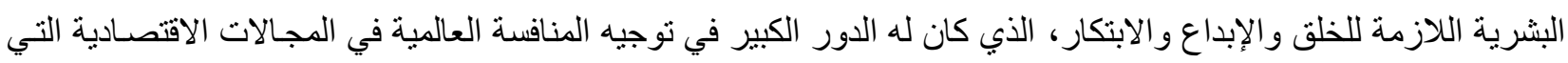
أدت إلى توجيه الاستثمار في مجالات المعرفة والبحث العلمي وهكذا اصبح للتعليم الجامعي دور كبير في تطوير المهارات

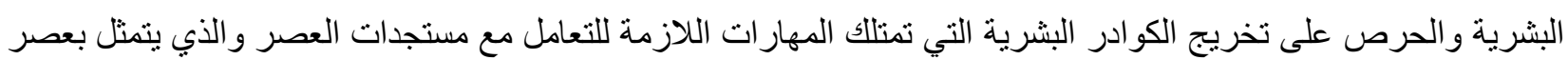
المعلومات و التطور ات و التكتلات الاقتصادية و التنافسية(').

ان للتعليم الجامعي دور كبير في ترشيد وتنظيم القوى العاملة الماهرة لأن هذه القوى هي صانعة للتقدم الاقتصـادي

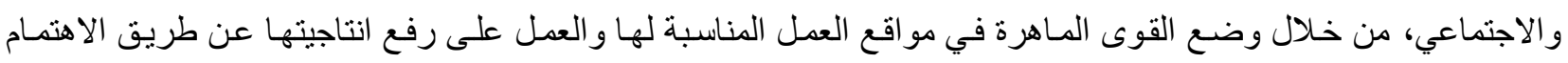

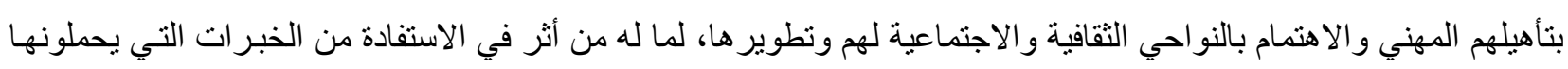

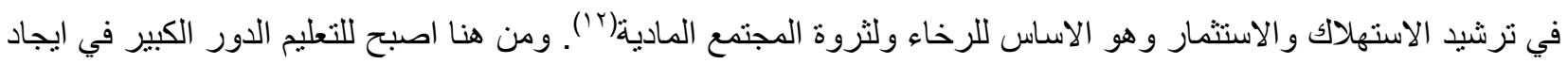
فرد واعي ومثقف و العمل على تزويده بالمهارات و القدرات اللازمـة لجعل طريقة أدائه للعهل أكثر كفاءة وبالتـالي تحسين

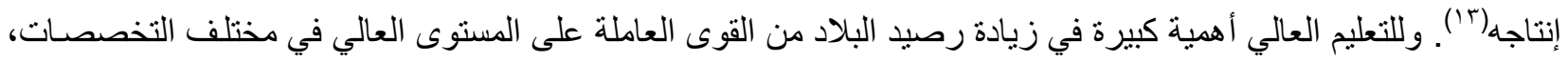

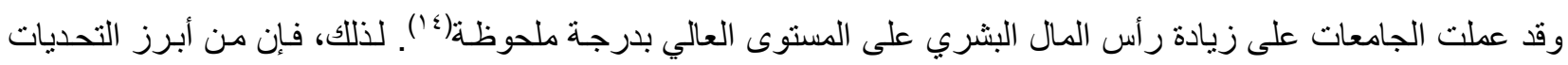

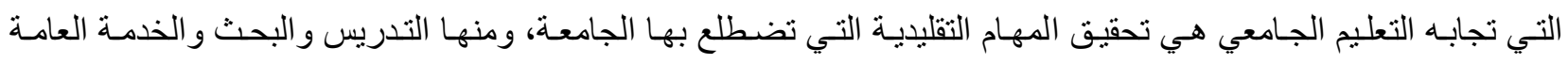

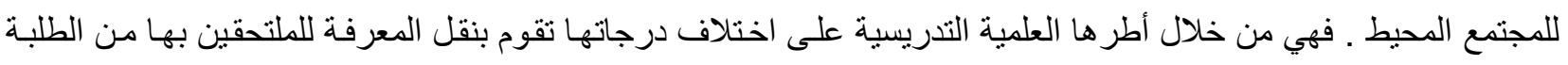

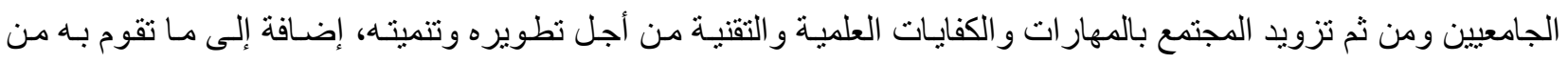

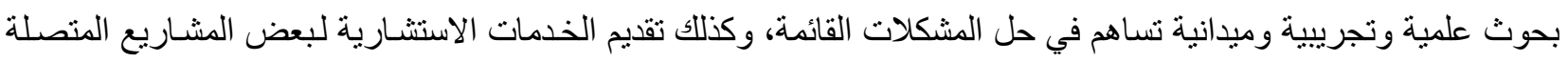

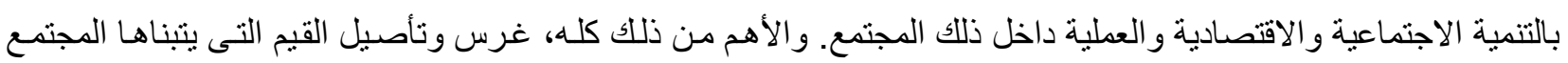
الذي تخدمه(10).

ثالثاً: الجودة الثاملة ووظائف الجامعة

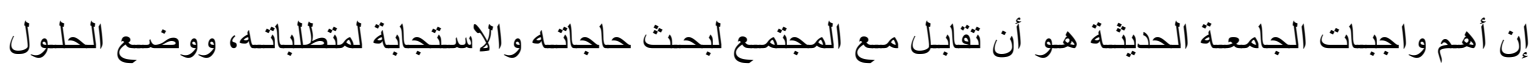

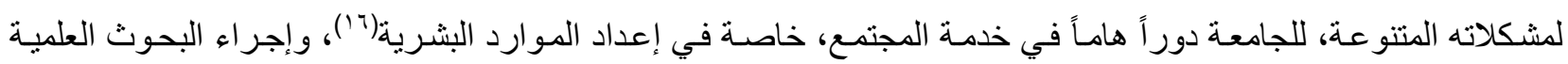
و المساهمة في عملية التنشئة الاجتماعية وخدمة المجتمع. ومن هذا المنطلق يمكننا أن نحدد فيما يلي وظائف الجامعات متمثناً في ثلاث وظائف رئيسية متكاملة: أـ الوظيفة الأولى: إعداد القوى البشرية العالية المستوى: يقوم التعليم بمؤسساته على اختلاف مستو ياتها و أنو اعها بإعداد

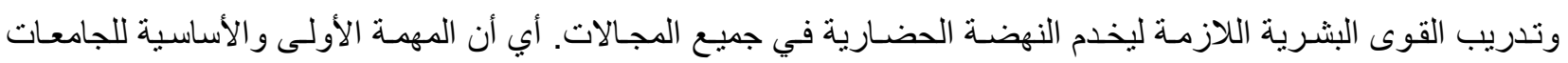

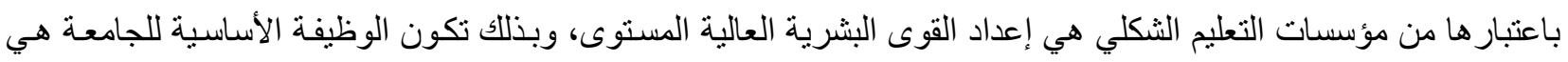

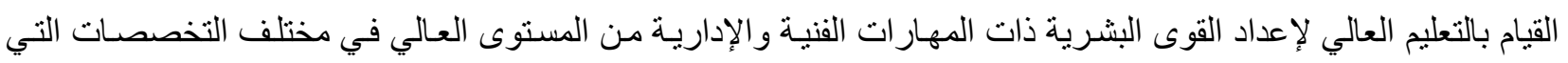

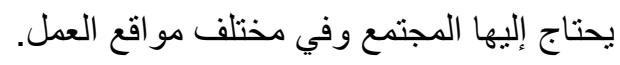


يُعد التعليم العالي الركيزة الأساسية لر أس المال البشري في مجال البحث العلمي والتطور التقني ومد المجتمع بنخبة

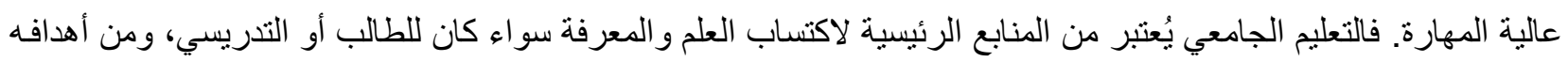

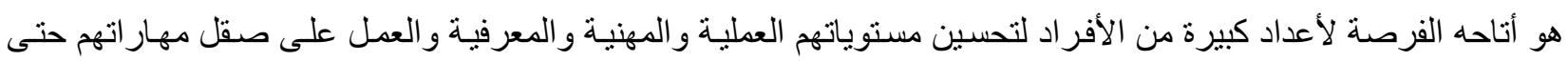

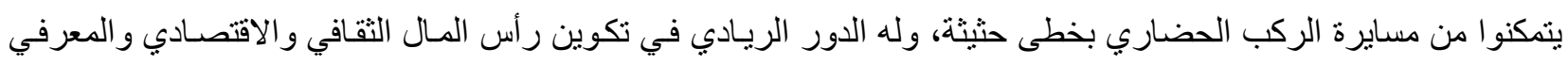
و المهني و العمل على تهيئة الفرد لسوق العمل من خلال تحفيز الطاقات الذهنية وتحريك القدرة الابتكارية وأضافه زخماً معرفياً

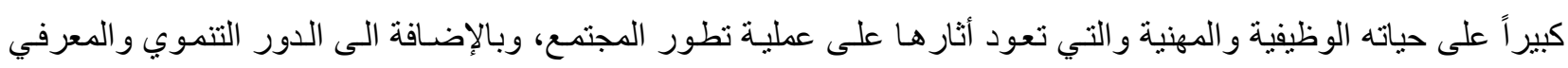

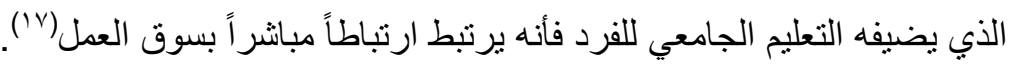
بـ الوظيفة الثانية: البحث العلمي : تنطلع الآن كل الثـعوب و المجتمعات إلى تحقيق التنميـة الثـاملة من أجل الوصول إلى الرفاهية المنشودة، حتى أطلق البعض على هذا العصر أسم عصر التتمية، ونواجه المجتمعات في الحقيقة خلال كفاحها المرير

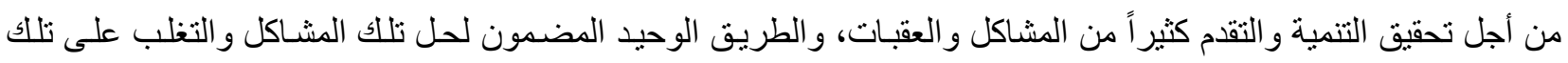
العقبات هو البحث العلمي، ومن هنا فقد لجأت كل المجتمعات إلى الجامعة تطلب منها العون في بحث مشـاكلها في كل منـاحي

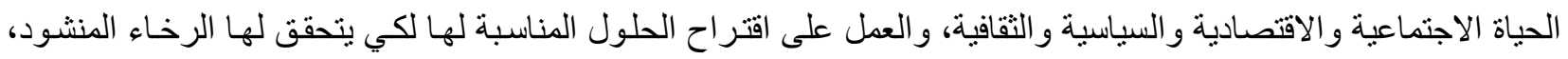

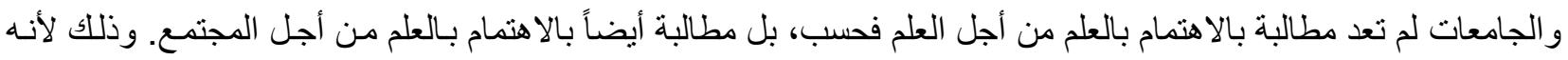

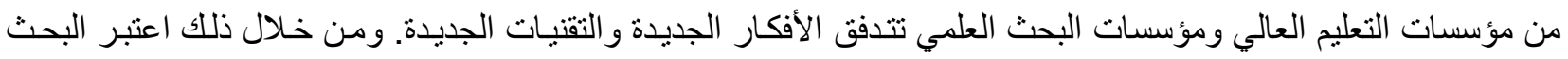

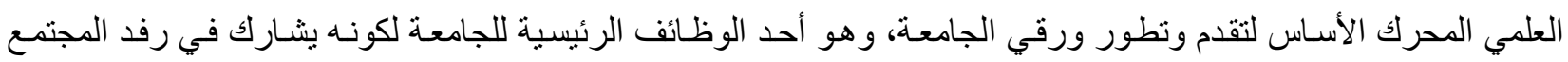

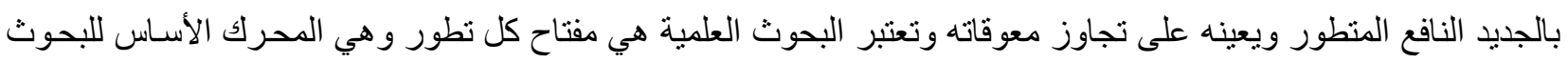

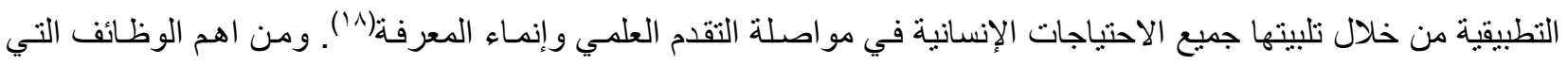

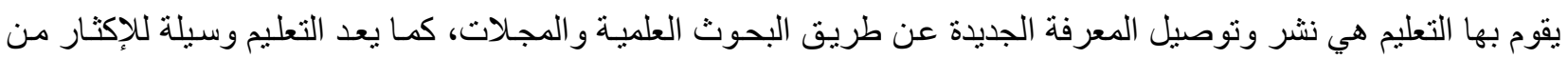

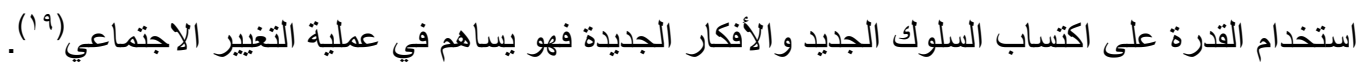
تـ الوظيفة الثالثة: خدمة المجتمع: تتلخص الوظيفة الثالثة للجامعة في المشـاركة في تقدم المعرفة وتثـيع القيم الأخلاقية

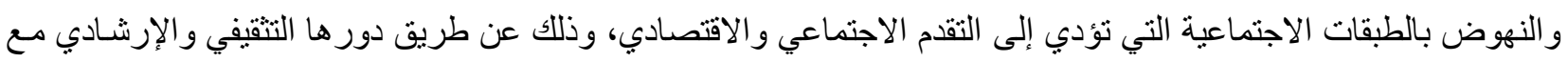
تبسيط المعارف الجديدة، و المحافظة عليها وتتميتها وتوصيلها إلى نسبة كبيرة من السكان في الصورة التي ولتي تخدم أهداف التتميـة

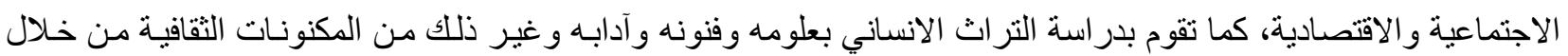

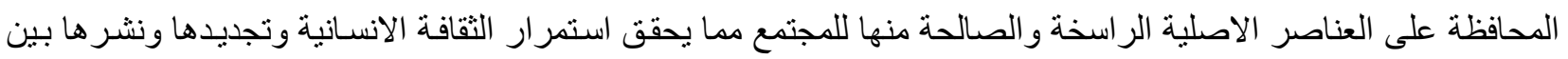
أفر اد الثعب. ان للتقدم المعرفي و العلمي دور فعال ومؤثر في التقدم الثقافي من خلال ما يقدمه من الابتكار و التجديد المعرفي التي

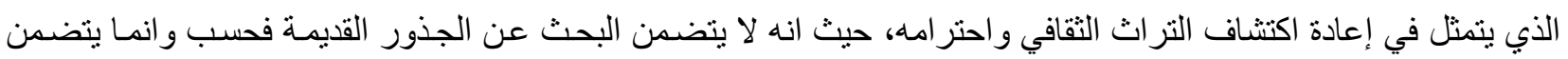

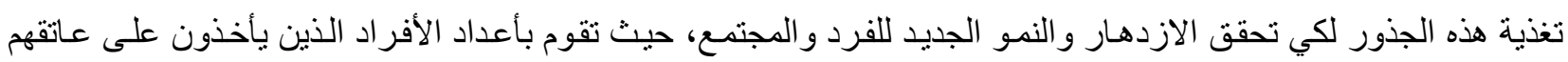
مسؤولية تقديم الجهود في نطاق البحث العلمي والتطوير التكنولوجي في المجتمع والمشاركة الفعالة في هذه الجهود.

رابعاً: معايير الجودة في التعليم

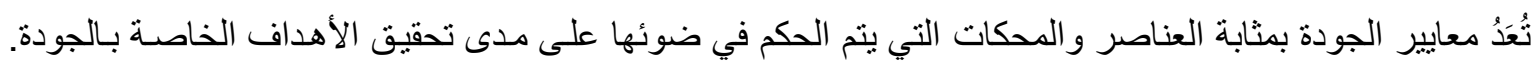

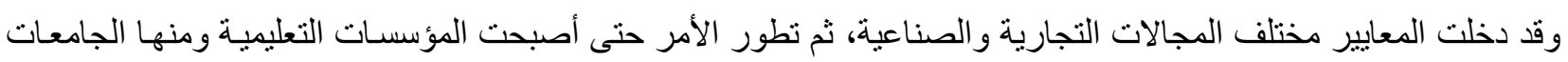
تخضع لتطبيق معايير ومقاييس عالمية لضمان جودة التعليم. ومن ثم سـارعت مختلف الجامعات بالعديد من دول العالم بتبني فكر الجودة في الأداء وتطبيق معايير الجودة على ما تقدمه من خدمات وما تستخدمه من وسائل حتى تؤدى رسالتها كمؤسسـات 
تربوية فاعلة في الهتمع. و هذه المعايير عبارة عن مجموعة مقاييس محددة للمقارنـة والحكم تستعمل لوضع أهداف وتقييم الإنجاز وقد تكون معبرة عن المستويات الحالية للإنجاز في المؤسسة، وقد تكون هذه المعايير أيضـاً عبارة عن مستويات تضعها إحدى الجهات الخارجية أو مستويات إنجاز في مؤسسة أخرى يتم اختيار ها للمقارنة. ويعمل النظام التعليمي كأي نظام

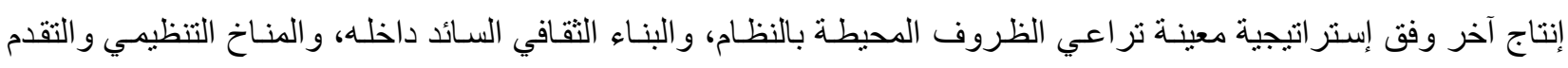

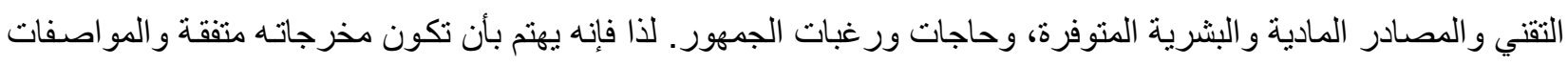
العالمية لضبط جودة الإتتاج من خلال السعي الدائم إلى استخدام معايير لقياس الجودة وضبطها. وسنعرض فئرة فيما يلي لأهم هذه المعايير.

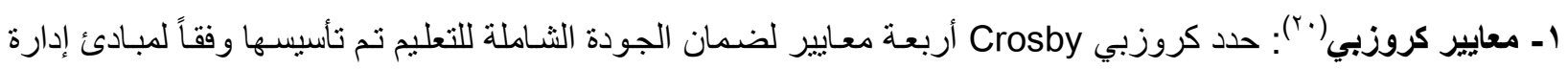

الجودة الثشاملة:

أـ التكيف مع منطلبات الجودة من خلال وضع تعريف محدد وواضح ومنسق للجودة. بـ وصف نظام تحقيق الجودة للوقاية من الأخطاء بمنع حدوثها من خلال وضع معايير للأداء الجيد. ت- منع حدوث الأخطاء من خلال ضمان الأداء الصحيح من المرة الأولى. ثـ تقويم الجودة من خلال قياس دقيق وفقا للمعايير الموضوعية الكيفية والكمية. r- معايير بلارج: طور مالكوم بلدرج M. Baldrige نظاماً لضبط الجودة في التعليم، وتم إقر اره كمعيار معترف بـه لضبط الجودة والتميز في الأداء بالمؤسسات التعليمية، وذلك حتى تتمكن المؤسسات التعليميـة من مواجهة المنافسـة القاسية في ضوء

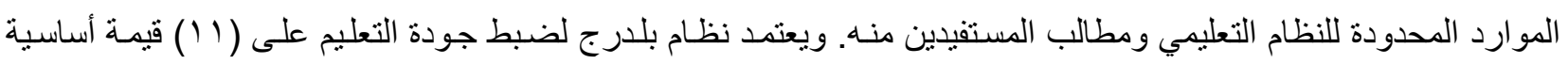

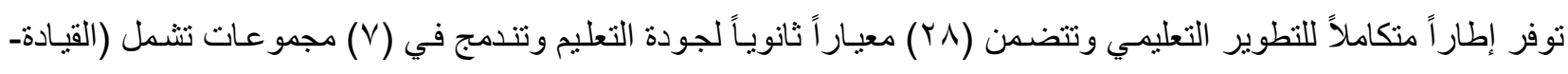

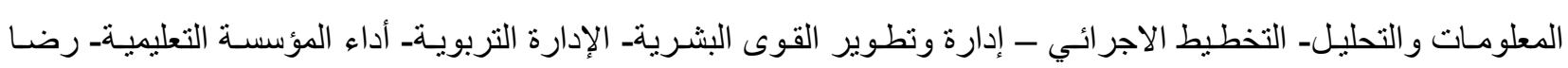
المستفيدين عن النظام)(r) (r) بـ معايير التقويم الثامل: قدمت حركة التقويم الذاني الثـامل للتعليم بعض المعايير التي تضمن شموله، وطور أنصسارها

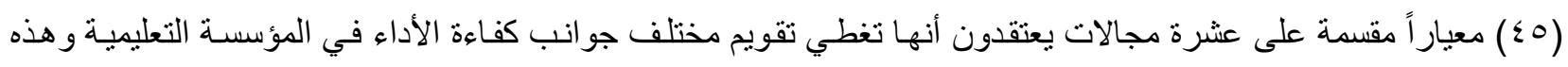

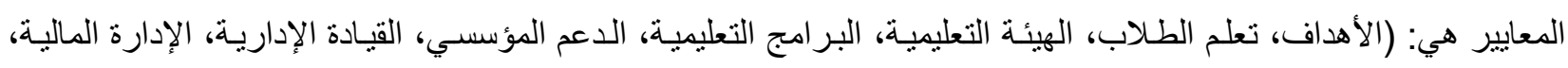

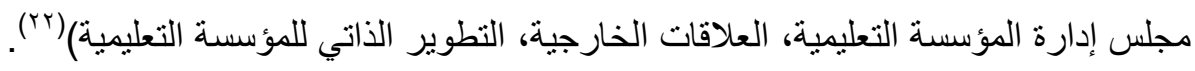
المبحث الثالث: الإجراعات المنهجية للاراسة أولاً: ادوات الدراسة ا ـ منهج الدراسة: ويعتمد البحث على المنهج الوصفي التحليلي لوصف وتشخيص موضوع البحث بهدف لفت النظر إلى أبعاد هذا الموضوع. rـ أدوات الدراسة 
أـ في الجاتب النظري: تم توظيف أساليب بحث عديدة لغرض تغطية البيانات المطلوبة لإعداد الجانب النظري و الميداني فقد

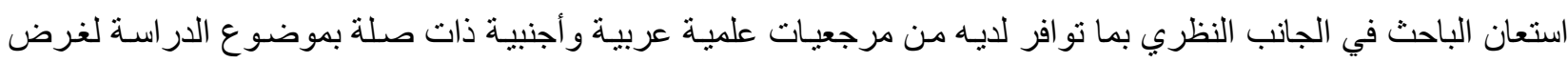
الوصول إلى إطار علمي واضح.

ب- في الجانب الميداني: اعتمد الباحث استمارة الاستبيان بوصفها أداة رئيسة في جمع البيانات وقد روعي في صياغتها بما

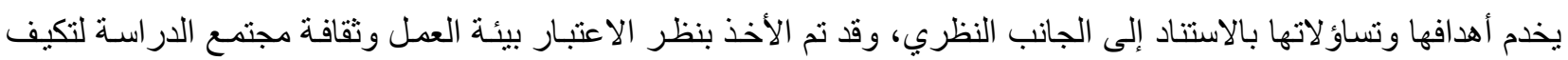
و إعداد صياغة فقرات الاستمارة بما يتلائم وموضوع الدراسة، وفي الآتي وصف لمحتويات الاستبانة المعتمدة: ـ ـ معلومات عامة تعريفية عامة عن الأفر اد المبحوثين و التي تتمثل بـ (العمر ، و الجنس، والحالة الاجتماعية، و التحصيل

$$
\text { الدر اسي، و الدرجة العلمية، و المنصب، و الخبرة). }
$$

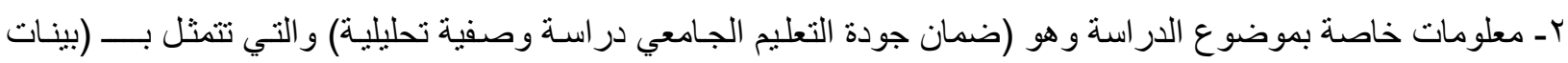
عن جودة التعليم من وجهة اعضاء هيئة التدريس، وأهم المعوقات التي تحول دون استفادة الكلية من تطبيق الجودة الثـاملة)

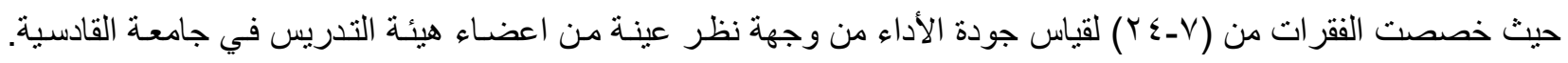

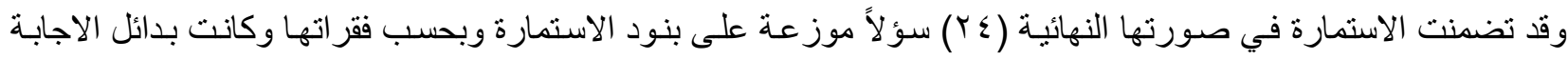
حسب مقياس ليكرت (Likert) ويتميز هذا المقياس بالسـهولة النسبية في حسـاب درجـات فقرات الاستبانة و الدرجـة الكليـة ومقارنتها بغير ها من الدرجات. ووفقاً لهذا المقياس فقد روعي وضع متدرج خماسي امام كل فقرة من فقرات الاستبانة، حيث

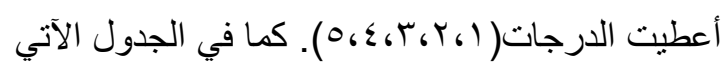

جدول (ץ) أوزان بدائل الاستجابة على المقياس

\begin{tabular}{|c|c|c|c|c|c|}
\hline غير موافق تماماً & غير موافق & غير متأكد & موافق & موافق تماماً & \\
\hline 1 & $r$ & $r$ & $\varepsilon$ & 0 & \\
\hline
\end{tabular}

r- مجتمع وعينة الدراسـة: لقد جاء اختيار الباحث لجامعة القادسية كمجتمع للار اسـة، وفي وصف لجامعة القادسية، هي

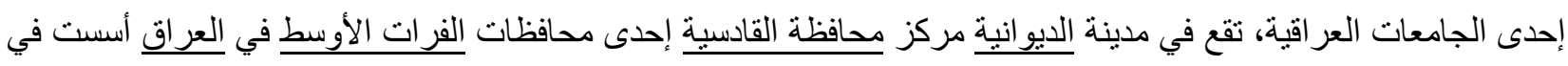

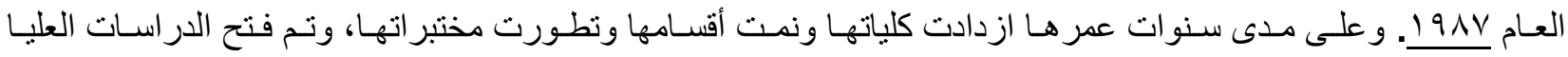
الماجستير و الدكتور اه في كلياتها، وهي مستمرة في جهودهـا لترتقي بخططها المستقلية بمـا يليق بها صـرحا علميـاً نقافياً و واجتماعياً ينير ظلام الجهل ويحاصر هو امش التخلف ويقضي عليها بما يعكس حضـارة العراق وتاريخه المشرق ومستقبله

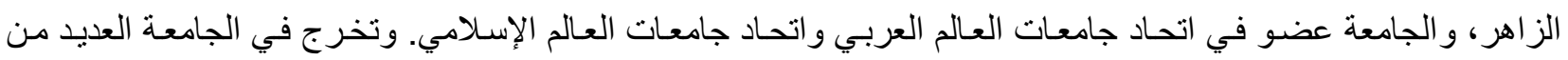
الطلبة العرب خاصة من الأردن وفلسطين و اليمن، و أعداد من المغرب العربي مثل تونس و المغرب. وتمثلت عينـة الدراسـة وهئ

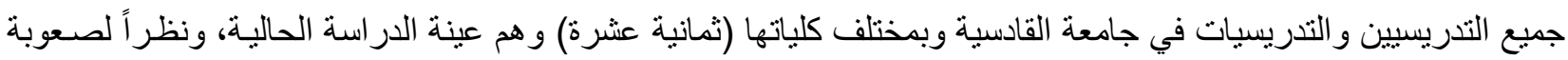
در اسة جميع أفر اد مجتمع البحث وما تقتضيه طبيعة هذه الدراسة تم استخدام العينة (العمدية) وذللك لما تتمتع به من سهولة في في ونه

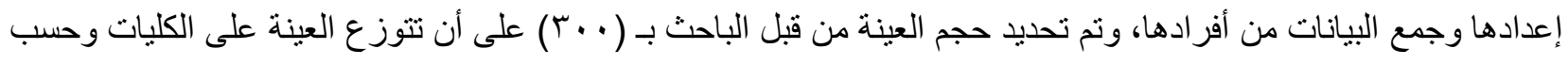

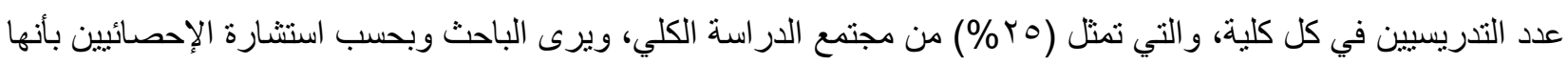

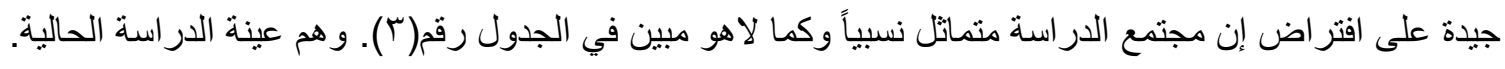
جدول (r) احصائية اعداد التدريسيين في جامعة القادسية

\begin{tabular}{|c|c|c|c|c|c|c|}
\hline المجمو & الجنس & التخصص & الشهادة & اللقب العلمي & مكان العمل & ت \\
\hline
\end{tabular}




\begin{tabular}{|c|c|c|c|c|c|c|c|c|c|c|c|c|c|}
\hline$\varepsilon$ & 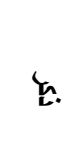 & Q: & $\frac{\xi}{5}$ & $\underline{\underline{t}}$ & $\begin{array}{l}c \\
\hat{b} \\
\underline{c}\end{array}$ & . & $\stackrel{0}{\varphi_{2}}$ & $\begin{array}{l}5 \\
\xi \\
\xi \\
\xi \\
\xi\end{array}$ & $\underset{\xi}{E}$ & $\begin{array}{l}\stackrel{5}{5} \\
\underline{E} \\
\underline{E} \\
\underline{E}\end{array}$ & $\underline{\tilde{E}}$ & & \\
\hline r. & $1 T$ & $v$ & 10 & 0 & . & $1 \varepsilon$ & 9 & 11 & $r$ & $\varepsilon$ & r & رئاسة الجامعة & 1 \\
\hline Or & $r r$ & $r \cdot$ & $\leqslant 9$ & $r$ & $\cdot$ & $\varepsilon r$ & 9 & $r$. & 0 & 0 & $\cdot$ & كلية علوم الحاسبات & $r$ \\
\hline IV & $1 \varepsilon$ & $r$ & · & IV & · & 9 & $\Lambda$ & 0 & $\varepsilon$ & v & 1 & كلية الآثار & $r$ \\
\hline $1 \cdot r$ & 10 & $r v$ & $r$ & 99 & . & $\leqslant 0$ & OV & 19 & $\varepsilon r$ & $r \varepsilon$ & 7 & كلية الآداب & $\varepsilon$ \\
\hline 11. & $\mathrm{VA}$ & $r r$ & $1 . r$ & $\mathrm{~V}$ & 17 & 09 & $r \Lambda$ & $\varepsilon$ & $r r$ & TV & 1. & ولاية الادارة & 0 \\
\hline$Y \wedge \varepsilon$ & $\begin{array}{l}11 \\
\varepsilon\end{array}$ & $1 \cdots$ & ITV & $1 \leqslant V$ & . & 104 & $1 \pi 1$ & $V \leq$ & $1 \cdot V$ & $V 4$ & YV & كلية التربية & 7 \\
\hline$V^{T}$ & $v$. & $r$ & vi & $r$ & $\cdot$ & ro & $\varepsilon \wedge$ & 17 & $r$. & YI & 7 & كلية التربية & $\mathrm{V}$ \\
\hline 10 & $r$ & Ir & 9 & 7 & $\cdot$ & 9 & 7 & $\mathrm{~V}$ & $r$ & $r$ & $r$ & كلية التربية & $\Lambda$ \\
\hline 11 & 9 & 9 & 11 & $\cdot$ & $\cdot$ & v & 11 & $r$ & $\mathrm{v}$ & $\mathrm{v}$ & 1 & كلية التقانات & 9 \\
\hline$r \cdot$ & 11 & 9 & 19 & 1 & . & $1 \leq$ & 7 & Ir & 0 & $r$ & $\cdot$ & كلية التمريض & 1. \\
\hline$\leqslant 1$ & $r$. & 11 & rq & $r$ & . & $r V$ & $1 \varepsilon$ & 19 & $\Lambda$ & 11 & $r$ & كلية الزراعة & 11 \\
\hline$r \varepsilon$ & 17 & $\Lambda$ & $r r$ & 1 & $\cdot$ & IV & $\mathrm{V}$ & 10 & $r$ & 0 & 1 & كلية الصيالة & Ir \\
\hline IYY & A. & $\varepsilon r$ & 111 & $\varepsilon$ & $\cdot$ & $r \varepsilon$ & $\Lambda \Lambda$ & $r \cdot$ & $0 \leq$ & $\varepsilon r$ & 7 & كلية الطب & IT \\
\hline 119 & 70 & $0\}$ & 119 & $r$ & . & 1.1 & 11 & Or & « & rI & $r$ & كلية الطب & $1 \leqslant$ \\
\hline $\mathrm{Vq}$ & $\leqslant 0$ & $r \varepsilon$ & $\sqrt{V 4}$ & $r$ & $\cdot$ & 0. & $r q$ & $r 4$ & $r \varepsilon$ & IV & $r$ & كلية العلوم & 10 \\
\hline Ir & Ir & . & $r$ & 1. & $\cdot$ & $r$ & 9 & $r$ & 0 & $r$ & 1 & كلية الفنون & 17 \\
\hline$\varepsilon 1$ & $r \mu$ & 10 & 1 & $\varepsilon V$ & 1 & $r r$ & 10 & $1 \varepsilon$ & 11 & 17 & $\cdot$ & كلية القانون & IV \\
\hline 99 & 89 & $r \cdot$ & 90 & $\varepsilon$ & 1 & $4 \pi$ & ro & 01 & $r q$ & 9 & $\cdot$ & كلية الهندسة & 11 \\
\hline 14 & 9 & $\mathrm{v}$ & 14 & $\cdot$ & $\cdot$ & 0 & $\Lambda$ & $\varepsilon$ & $\varepsilon$ & 0 & $\cdot$ & الاسنان & 19 \\
\hline $1 \times 41$ & $\begin{array}{c}\Lambda \varepsilon \\
0\end{array}$ & $\varepsilon r \mu$ & 9.7 & ri & 11 & $V \cdot v$ & $0 \leqslant \pi$ & $\{\pi$ & $\{01$ & r17 & $v$. & مجموع & \\
\hline & \multicolumn{2}{|c|}{$1 \times 41$} & $1 Y 41$ & \multicolumn{4}{|c|}{$1+41$} & \multicolumn{4}{|c|}{ IYMA } & \multicolumn{2}{|c|}{ المجموع الكلي } \\
\hline
\end{tabular}

لقد قام الباحث باختيار عينة عمدية ومن كل كلية بو اقع (\% \% ) من عدد التدريسيين في هذه الكليات وزعت عليهم استمارة الاستبيان لغرض الحصول على إجاباتهم على فقرات هذا الاستبيان. إذ تم توزيع (بسب)استمارة على مجموعـة من

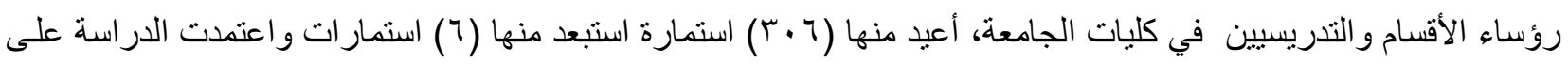

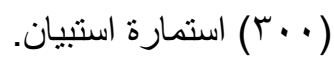

عـ نوع الدراسة: لقد صمم هذا البحث ليكون بحثناً وصفياً يستطلع الظاهرة المدروسـة وأسبابها ونتائجها بشكل عـام. ولذلك عمل الباحث إلى استخدام الطريقة الميدانية وسيلة للحصول على البيانات الاساسية التي يحتاجها البحث. 
هـ مجالات الدراسة

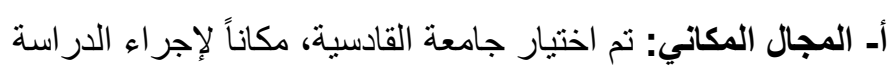

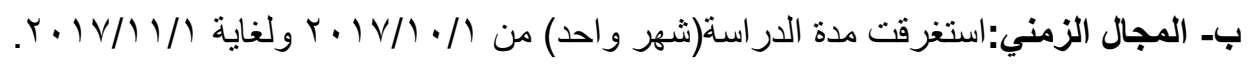
ج- المجال البشري: شمل اعضاء الهيئات التدريسية في كليات جامعة القادسية. المبحث الرابع: عرض نتئج الاراسة الميدانية أولاً: عرض الخصائص الثخصية لعينة الدراسة 1- الفئات العمرية:

جدول(r) توزيع الفئات العرية لعينة الدراسة

\begin{tabular}{|c|c|c|c|c|c|c|c|c|c|}
\hline \multicolumn{10}{|c|}{ الفئات العمرية } \\
\hline \multicolumn{2}{|c|}{ • •- فأكثر } & \multicolumn{2}{|c|}{09.0.} & \multicolumn{2}{|c|}{$\leqslant 9-\varepsilon}$. & \multicolumn{2}{|c|}{ rq_r. } & \multicolumn{2}{|c|}{ rq.r. } \\
\hline$\%$ & العدد & $\%$ & العدد & $\%$ & العدد & $\%$ & العدد & $\%$ & العدد \\
\hline $\mathrm{V}, \mathrm{V}$ & $r r$ & $9, V$ & rq & $\begin{array}{l}\text { IV } \\
\mathrm{V}\end{array}$ & or & $\varepsilon \cdot, r$ & $|Y|$ & $Y \leqslant, Y$ & $V \varepsilon$ \\
\hline
\end{tabular}

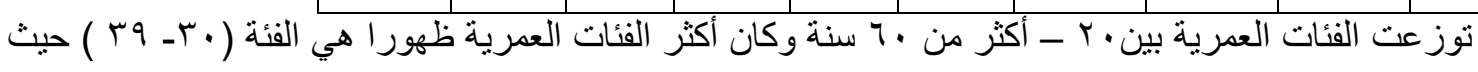

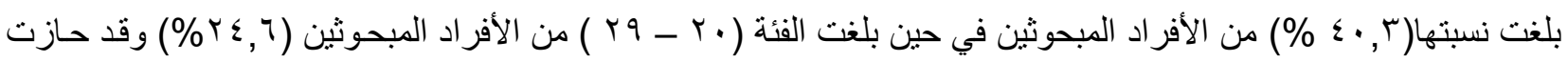

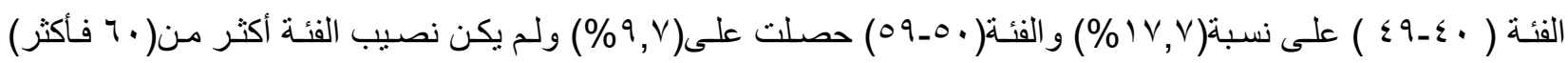

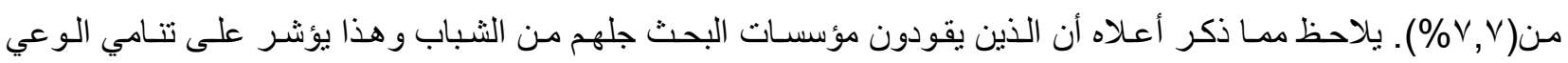

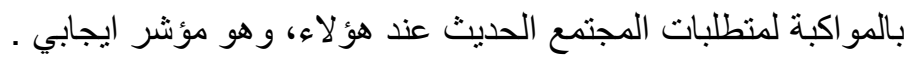
r- الجنس والحالة الاجتماعية: جدول(؛ ) توزيع عينة الدراسة حسب الجنس والحالة الاجتماعية لعينة الدراسة

\begin{tabular}{|c|c|c|c|c|c|c|c|}
\hline \multicolumn{8}{|c|}{ الجنس والحالة الاجتماعية } \\
\hline \multicolumn{2}{|c|}{ اعزب } & \multicolumn{2}{|c|}{ متزوج } & \multicolumn{2}{|c|}{ انظى } & \multicolumn{2}{|c|}{ ذكر } \\
\hline$\%$ & 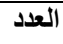 & $\%$ & 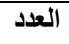 & $\%$ & العلد & $\%$ & العلد \\
\hline $\begin{array}{c}r r, \\
r,\end{array}$ & $9 V$ & $T V, V$ & $r \cdot r$ & $r \varepsilon, r$ & $1 \cdot 4$ & 90,1 & $19 \mathrm{~V}$ \\
\hline
\end{tabular}

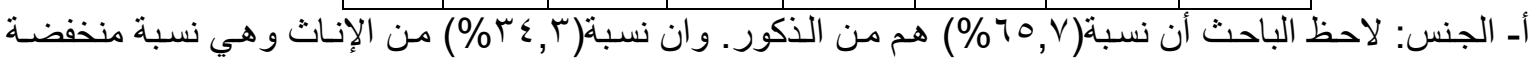

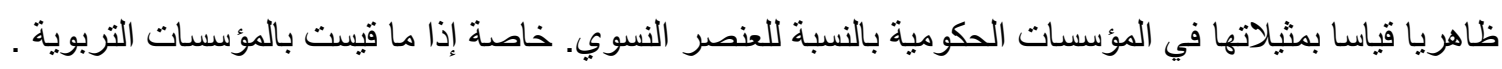

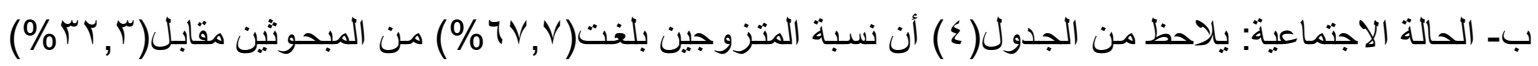
من غير المتزوجين معظمه من النساء.

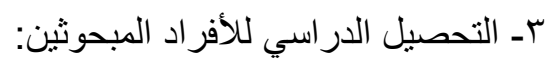

جدول(•) يبين التحصيل الدراسي لعينة الدراسة

\begin{tabular}{|c|c|c|c|}
\hline \multicolumn{4}{|c|}{ التحصيل الدراسي } \\
\hline \multicolumn{2}{|c|}{ ماجستير } & \multicolumn{2}{|c|}{ دكتوراه } \\
\hline$\%$ & العدد & $\%$ & العدد \\
\hline $09, V$ & 189 & $\varepsilon \cdot, r$ & $|r|$ \\
\hline
\end{tabular}

$-V \mid r$. 
يتضح من الجدول(0) أن الإفر اد الحاصلين على شهادة الدكتور اه بلغت نسبة(r, • ؛ \%) من الأفراد عينة الدراسـة

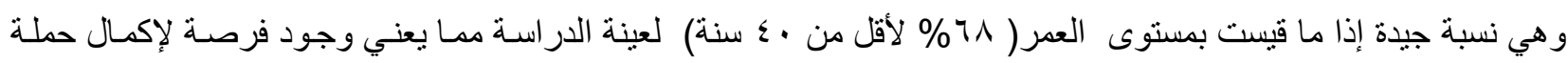

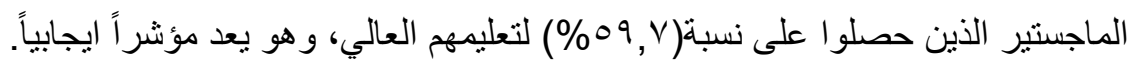

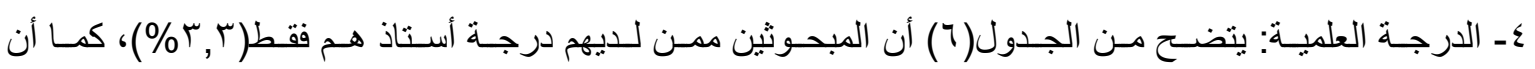

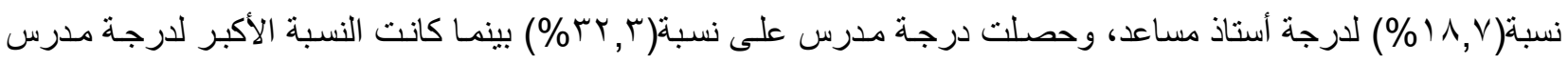
مساعد و هي(\%)

جدول(؟) يبين الارجة العلمية لعينة الدراسة

\begin{tabular}{|c|c|c|c|c|c|c|c|}
\hline \multicolumn{8}{|c|}{ الدرجة العلمية } \\
\hline \multicolumn{2}{|c|}{ مدرس مساعد } & \multicolumn{2}{|c|}{ مدرس } & \multicolumn{2}{|c|}{ استاذ مساعد } & \multicolumn{2}{|c|}{ استاذ } \\
\hline$\%$ & العدد & $\%$ & العدد & $\%$ & العدد & $\%$ & العدد \\
\hline$\varepsilon 0, V$ & $1 T V$ & $\begin{array}{c}r, \\
r,\end{array}$ & qV & $11, V$ & 07 & $r, r$ & 1. \\
\hline
\end{tabular}

هـ الخبرة العملية: لاحظ الباحث إن خبرة الأفراد نوزعت على الشكل الآتي:

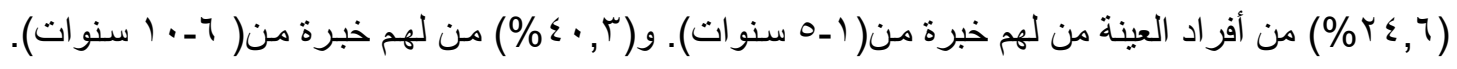

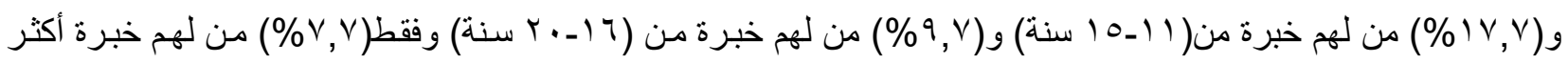

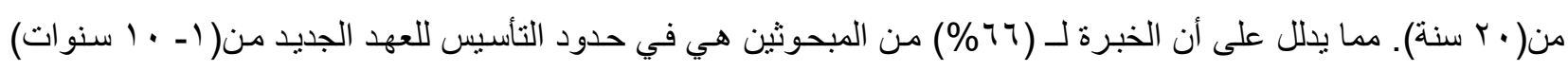

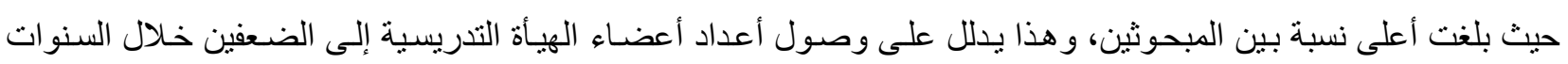
العشرة الماضية.

جدول (V) يبين الخبرة العملية لأفراد عينة الدراسة

\begin{tabular}{|c|c|c|c|c|c|c|c|c|c|}
\hline \multicolumn{10}{|c|}{ الخبرة الادارية } \\
\hline \multicolumn{2}{|c|}{ • r ـ فأكثر } & \multicolumn{2}{|c|}{$r \cdot-17$} & \multicolumn{2}{|c|}{10.11} & \multicolumn{2}{|c|}{$1 .-7$} & \multicolumn{2}{|c|}{$0-1$} \\
\hline$\%$ & العدد & $\%$ & العدد & $\%$ & العدد & $\%$ & العدد & $\%$ & العدد \\
\hline $\mathrm{v}, \mathrm{V}$ & $r r$ & $q, v$ & rq & $\begin{array}{l}\text { IV } \\
\mathrm{V}\end{array}$ & or & $\varepsilon \cdot, r$ & $|r|$ & $r \leqslant, 7$ & $V \varepsilon$ \\
\hline
\end{tabular}

ثانياً: الوصف الإحصائي.. عرض نتائج الاراسـة وتحليلها وتفسيرها لفقرات الاستبيان في سبل الارتقاء بجودة الاداء الجامعي من وجهة اعضاء هيئة التدريس التصنيس

جدول(9) الوسط الحسابي والانحراف المعياري والخطأ المعياري لإجابات العينة على الفقرة(^)

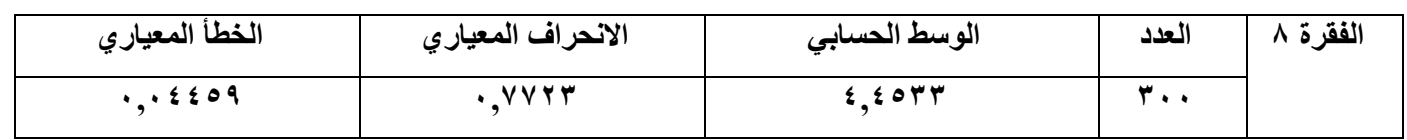

من الجدول (9) يتضح ان متوسط إجابات عينة البحث على الفقرة (^) الخاصة بـــ(ان الجامعات مطالبة بتوفير

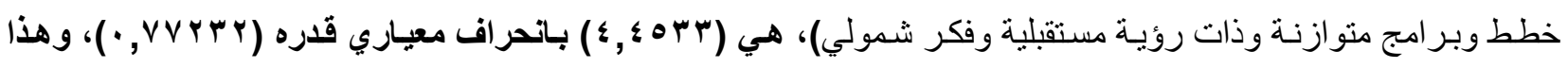
يعني أن أفراد كانوا متفقين مع هذه الفقرة. ويستهدف التعليم بشكل عام إلى رفع مستوى حياة الافراد تدريجيا عن طريق 
تلبية حاجياتهم الأساسية خاصة ونحن في بلد يتميز بمعدل تز ايد سكاني هام. وضرورة وجود أدلة وبر اهين لصالح التقنيات

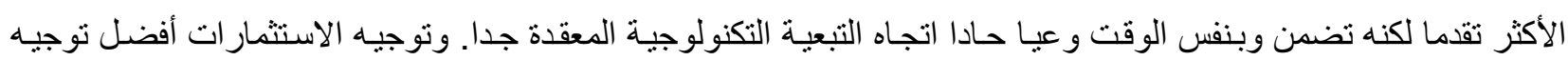

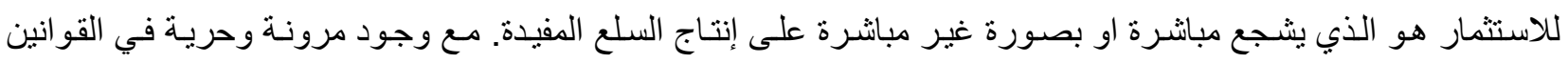
و اللو ائح المنظمة للعمل في كليات الجامعة لكي تتو اعم مع ما يطر أ على المجتمع من تغير ات تستدعي التنخل من قبل الجامعة. ولغرض التأكد فيما أذا كانت هذه الإجابـة تمثل آراء مجتمـع الدراسـة تم استخدام اختبار( T) المتوفر في البرنـامج الجـاهز

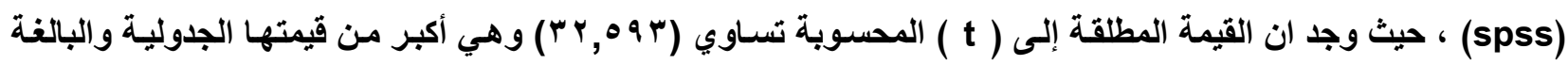

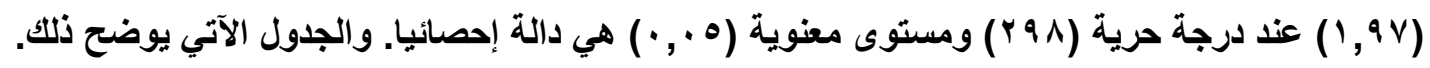

جدول(9 - ( ) الاختبار الاحصائي على الفقرة(^)

\begin{tabular}{|c|c|c|c|c|c|c|}
\hline \multicolumn{2}{|c|}{ درجة الثقة= 90\% } & \multirow{2}{*}{ الفتوسطات الفرق } & \multirow[t]{2}{*}{ معنوية الاختبار } & \multirow{2}{*}{ الحرية } & \multirow[t]{2}{*}{ اختبار t } & \multirow{3}{*}{ ف } \\
\hline الحد الاعلى & الحد الأدنى & & & & & \\
\hline 1,2011 & $1, r 707$ & 1,_ORTr & $\cdot, \cdots$ & $r 99$ & $r r, 09 r$ & \\
\hline
\end{tabular}

جذول ( • 1) الوسط الحسابي والاتحر اف المعياري والخطأ المعياري لإجابات العينة على الفقرة(9)

\begin{tabular}{|c|c|c|c|c|}
\hline الخطأ المعياري & الانحراف المعياري & الوسط الحسابي & العدد & ف 9 \\
\hline., $91 \vee 0$ & 1,01919 & r, r... & $r \ldots$ & \\
\hline
\end{tabular}

يظهر الجدول ( • (- ) البيانـات الخاصـة بالفقرة(9) والتي تنص بـ (اختز ال عملية التعليم في شخص واحد وهو

المحاضر وفي مصدر واحد وهو الكتاب الذي يعجز في كثير من الأحيان عن ملاحقة الرؤي الجديدة في عالم المعرفة)، فقد

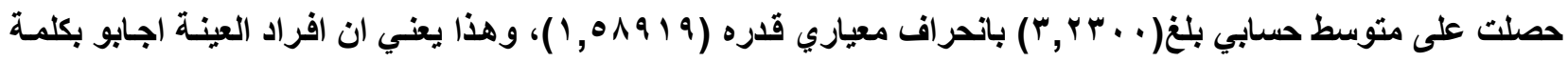

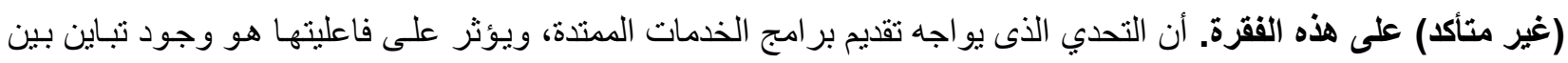

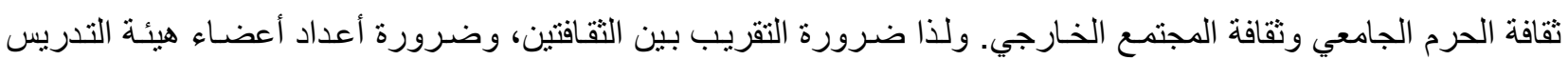

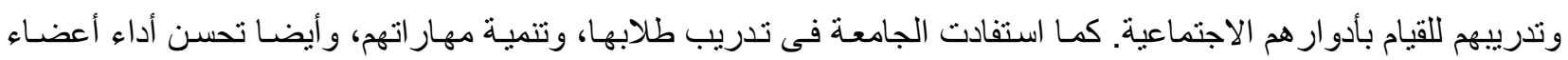
هيئة التدريس حيث اكتسبوا المزيد من الخبرات الميدانية، وتم تدعيم ميزانية الجامعة وتحديث الكثير من أجهزتها ومعاملها. ولغرض التأكد فيما اذا كانت هذه الاجابة تمثل آراء مجتمع الاراسة تم استخدان اختبار(t)، حيث وجد ان القيمـة المطلقة

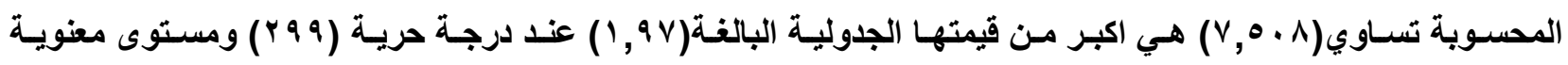

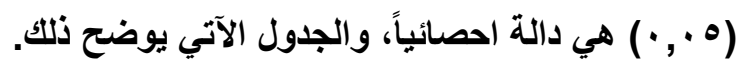

جلول(11 - 1 1 ) الاختبار الاحصائي على الفرة(9)

\begin{tabular}{|c|c|c|c|c|c|c|}
\hline \multicolumn{2}{|c|}{ درجة الثقة= ه9\% } & \multirow{2}{*}{$\begin{array}{l}\text { الفرق بين } \\
\text { المتوسطات }\end{array}$} & \multirow{2}{*}{ الاختبار } & \multirow[t]{2}{*}{ درجة الحرية } & \multirow[t]{2}{*}{ اختبارt } & \multirow{3}{*}{ ف } \\
\hline الحد الاعلى & الحد الادنى & & & & & \\
\hline$\cdot, \vee Y \vee \wedge$ & $\cdot, \leqslant Y \diamond 0$ & •, จレฯ & $\cdot, \cdots$ & rqq & $v, 0.1$ & \\
\hline
\end{tabular}

جدول(r I ) الوسط الحسابي والانحراف المعياري والخطأ المعياري لإجابات العينة على الفقرة(• ( )

\begin{tabular}{|c|c|c|c|c|}
\hline الخطأ المعياري & الانحراف المعياري & الوسط الحسابي & العدد & ف.1 \\
\hline$\cdot, \cdot \leq \leqslant \wedge \leqslant$ & $\cdot, V \vee T \vee Y$ & $\varepsilon, \xi \cdot 7 V$ & $m$ & \\
\hline
\end{tabular}


يعرض الجدول (r l ) الوسط الحسـابي والانحراف المعيـاري للفقرة ( • 1) التي تنص على (مو اكبة الجامعات

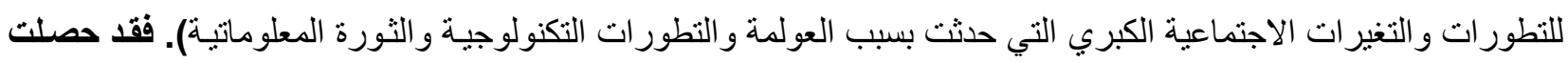

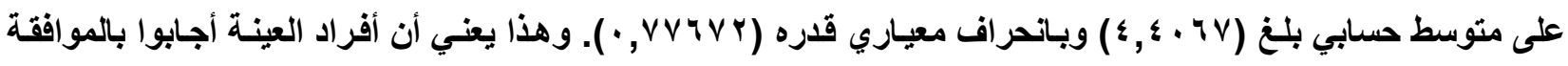

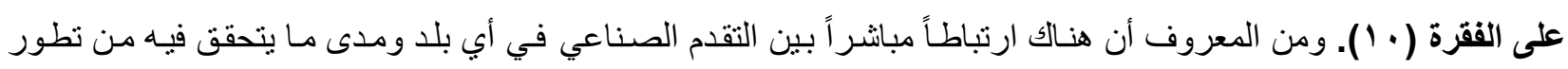

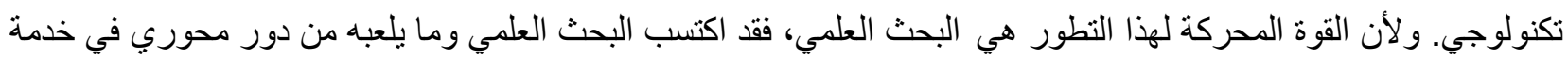
التنمية أهمية كبيرة تعاظمت في الفترة الأخيرة التي بدأت تشهـ تغيرات اقتصـادية كاسحة في ظل تحرير التجارة وقو انين

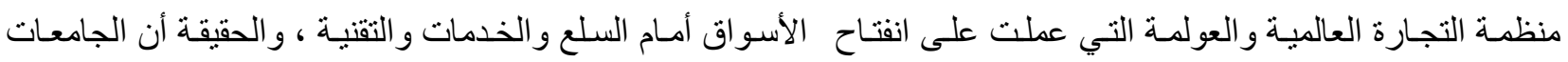
العر اقية تمتلك العديد من المر افق الخدمية والإنتاجية التي تمكنها من تقديم خدماتها للمجتمع وتحقيق رسالتها التعليمية و العملية نحو حل مشكلات المجتمع. ولغرض التأكد فيمـا أذا كاتت هذه الإجابـة تمثل آراء مجتمع الدراسـة تم استعمال اختبار( t )،

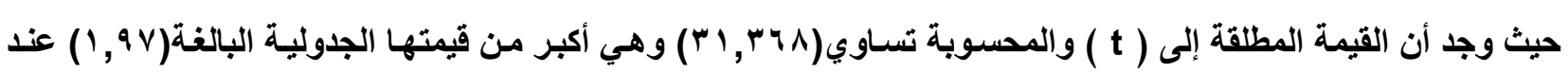

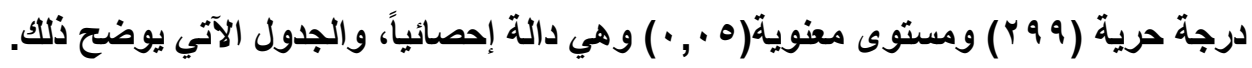

جدول(r I ـ ( ) الاختبار الاحصائي على الفقرة(· ( )

\begin{tabular}{|c|c|c|c|c|c|c|}
\hline \multicolumn{2}{|c|}{ درجة الثقة= 90\% } & الفرق بين & معنوية الاختبار & درجة الحرية & t اختبارt & ف.1 \\
\hline الحد الاعلى & الحد الادنى & & & & & \\
\hline $1, \leq 9 \leq 9$ & $1, \Gamma \backslash \wedge \varepsilon$ & $1, \varepsilon .77 \mathrm{~V}$ & $\cdot, \cdots$ & ५११ & r. & \\
\hline
\end{tabular}

جدول(r I ) الوسط الحسابي والاتحراف المعياري والخطأ المعياري لإجابات العينة على الفقرة(1)

\begin{tabular}{|c|c|c|c|c|}
\hline الخطأ المعياري & الاتحراف المعياري & الوسط الحسابي & العدد & ف 11 \\
\hline$\cdot, \wedge Y \Delta \varepsilon$ & $1, \leq \leq 799$ & r,YYrr & $\mu \ldots$ & \\
\hline
\end{tabular}

يبين الجدول(r I ) الوسط الحسابي والانحر اف المعياري للفقرة(1 (1) والتي تنص على(وجود علاقات مع العيئات

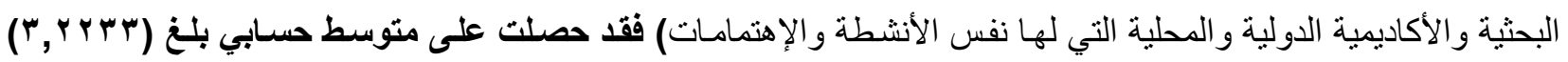

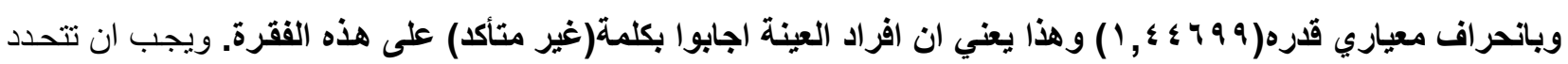

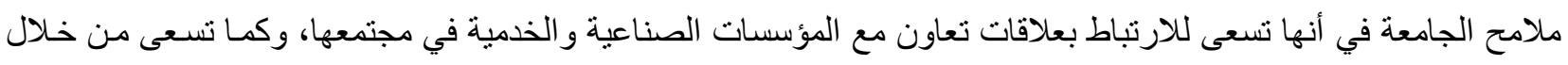

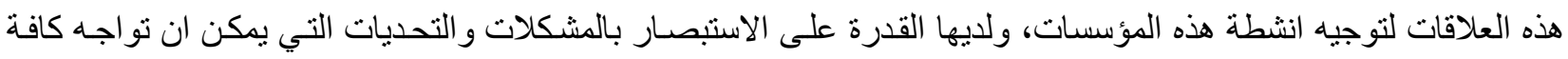

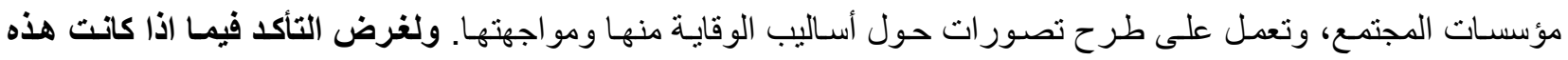
الاجابة تمثل آراء مجتمع الاراسـة تم استخدام اختبار(t)، حيث وجد ان القيمة المطلقة (t) والمحسوبة تسـاوي(Y,TVT)

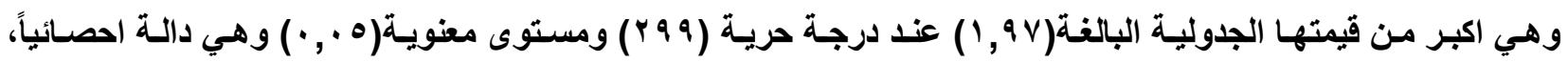
والجدول الآتي يوضح ذلك.

جدول (r I ) الاختبار الاحصائي على الفقرة (1)

\begin{tabular}{|c|c|c|c|c|c|c|}
\hline \multicolumn{2}{|c|}{ درجة الثقة } & \multirow{2}{*}{ المتوسطات الفرق بين } & \multirow{2}{*}{ الاختبار } & \multirow{2}{*}{ الحرية } & \multirow[t]{2}{*}{ اختبار t } & \multirow[t]{3}{*}{ ف 11 } \\
\hline الحد الاعلى & الحد الادنى & & & & & \\
\hline$\cdot, r \wedge \vee V$ & $\cdot, \cdot 091$ & • & $\because \cdots 1$ & $\begin{array}{r}r q \\
q\end{array}$ & $r, T V Y$ & \\
\hline
\end{tabular}


جدول(ء ( ))الوسط الحسابي والانحراف المعياري والخطأ المعياري لإجابات العينة على الفقرة( r ) )

\begin{tabular}{|c|c|c|c|c|}
\hline الخطأ العياري & الانحراف المعياري & الوسط الحسابي & عدد المفردات & ف r \\
\hline$\cdot, \nabla q \leq V$ & 1,rvчrq & r,rviv & $r \ldots$ & \\
\hline
\end{tabular}

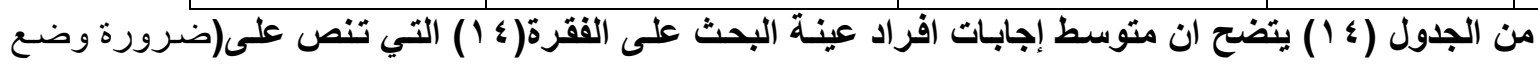

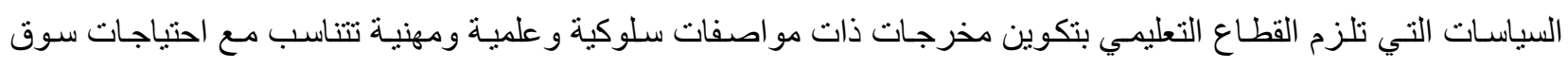

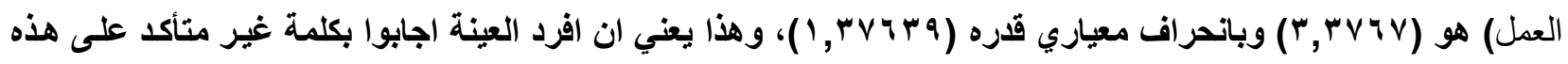

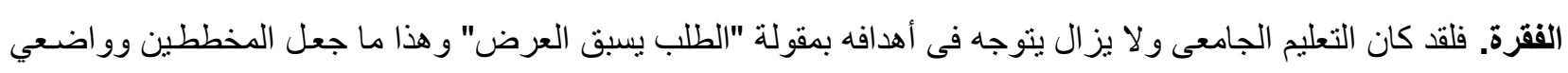

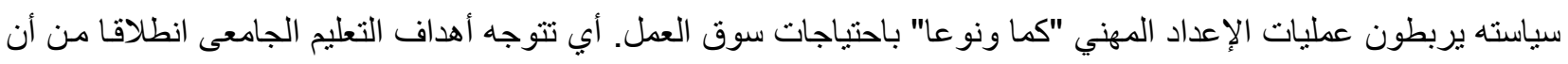

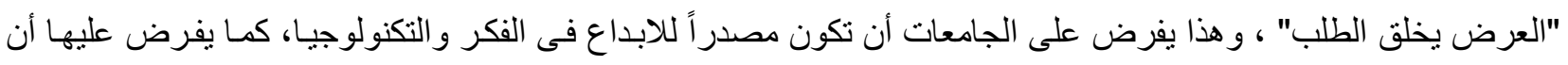

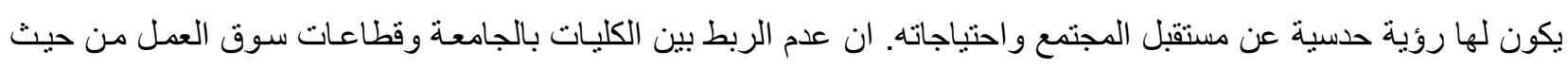

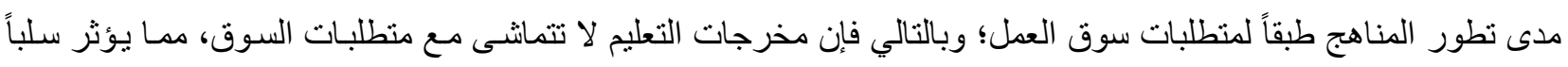

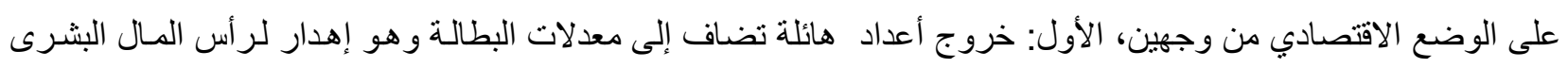

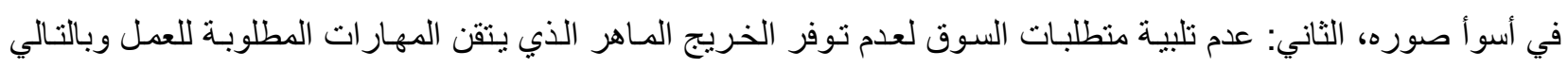

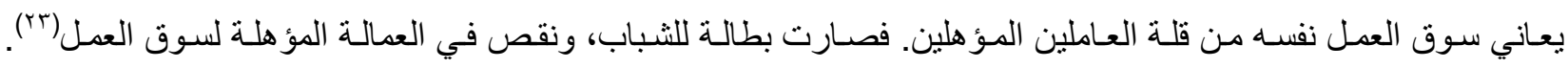
ولغرض التأكد فيما اذا كانت هذه الاجابة تمث آراء مجتمع الاراسـة تم استعمال اختبار(t)، حيث ان القيمة المطلقة إلى(t)

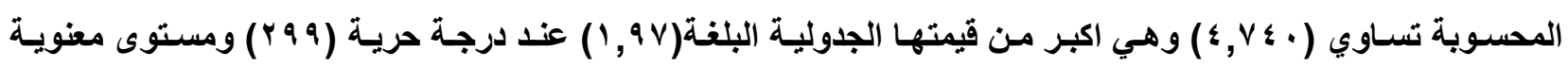

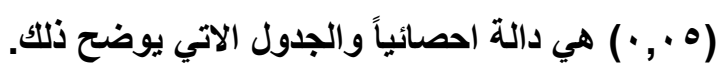

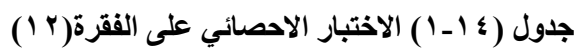

\begin{tabular}{|c|c|c|c|c|c|c|}
\hline \multicolumn{2}{|c|}{ درجة الثقة } & الفرق بين & معنوية الاختبار & درجة الحرية & اختبار t & فr| \\
\hline الحد الاعلى & الحج الادنى & T & & & & \\
\hline •, OHr. & $\cdot, Y r \cdot r$ & •, & $\bullet, \cdots$ & एqq & $\varepsilon, V \varepsilon$. & \\
\hline
\end{tabular}

جدول(0 1) الوسط الحسابي والانحراف المعياري والخطأ المعياري لاجابات العينة على الفقرة( ا I)

\begin{tabular}{|c|c|c|c|c|}
\hline الخطأ المعياري & الانحراف المعياري & الوسط الحسابي & عدد المفردات & ف سו \\
\hline$\because, \vee \vee 0 \leqslant 7$ & $1, \% \cdot 790$ & $r, 0 r \ldots$ & r.. & \\
\hline
\end{tabular}

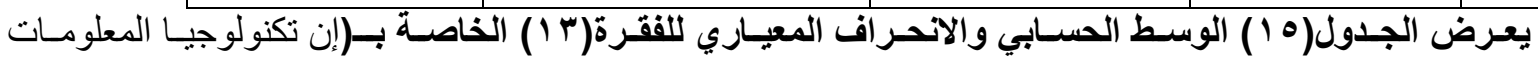

و الاتصال قد أتاحت خيارت جديدة للجامعات في كيفية تسيير التعليم العالي وفي الطرق المنهجية الجديدة في التدريس و التعليم)

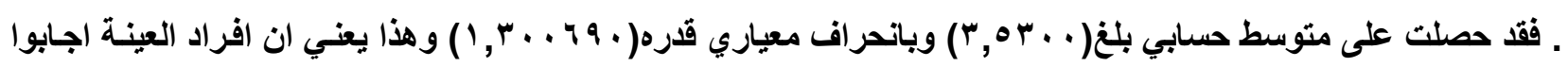

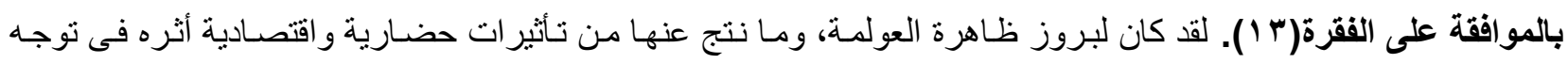

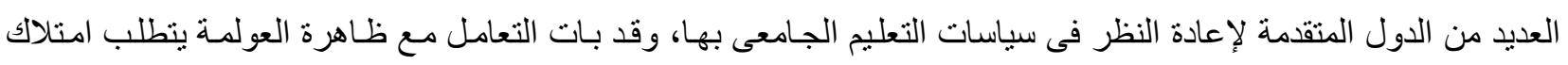

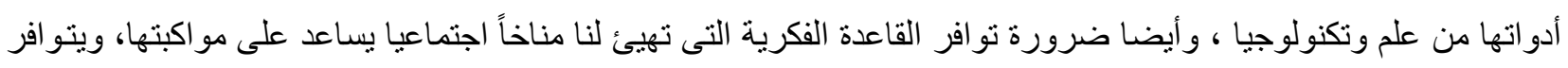

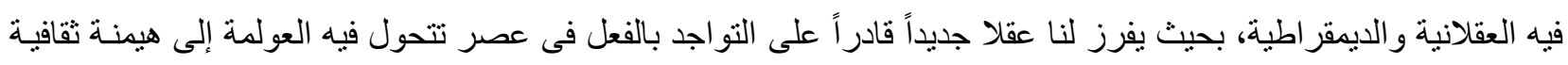

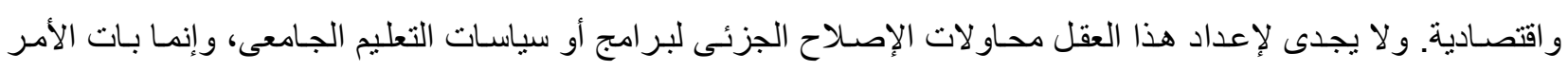

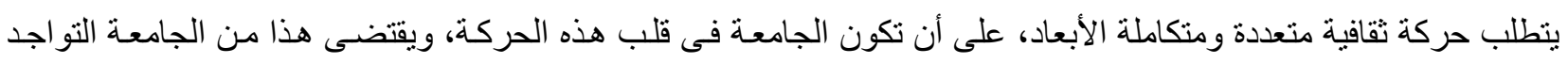


داخل المجتمع و الاشتباك و التفاعل مع كافـة المؤسسـات، وخاصـة تلك التىى لها دور فى إعداد هذا العقل المنشود. ولغرض معرفة فيما اذا كانت هذه الاجابـة تمثل آراء مجتمع الدراسـة تم استخدام اختبار(t)، حيث وجد ان القيمـة المطلة الى (t)

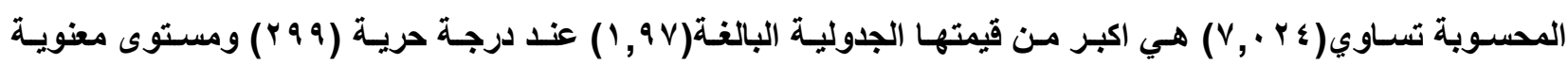

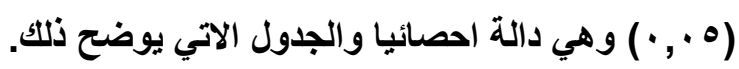

جدول (10 - 1) الاختبار الاحصائي على الفقرة( ) 1 )

\begin{tabular}{|c|c|c|c|c|c|c|}
\hline \multicolumn{2}{|c|}{ درجة الثقة= ه9\% } & الفرق بين & معنوية & درجة الحرية & اختبار t & ف rا \\
\hline الحد الاعلى & الحد الادنى & & & & & \\
\hline$\cdot, 7 \vee \wedge 0$ & $\cdot, r \wedge 10$ & .,०r... & $\cdot, \cdots$ & rqq & $V, P \xi$ & \\
\hline
\end{tabular}

جدول (7 1 ) الوسط الحسابي والانحر اف المعياري والخطأ المعياري لاجابات العينة على الفقرة( ؛ ( )

\begin{tabular}{|c|c|c|c|c|}
\hline الخطأ المعياري & الانحراف المعياري & الوسط الحسابي & عدد المفردات & فـ \\
\hline$\cdot, \cdot \leqslant r \wedge q$ & $\cdot, V \leq r \vee q$ & $\{, 01 \ldots$ & r.. & \\
\hline
\end{tabular}

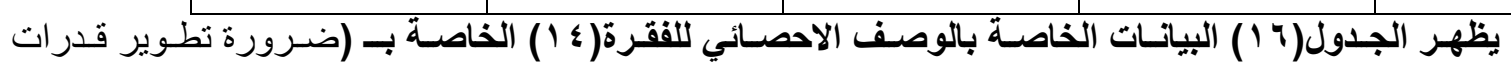

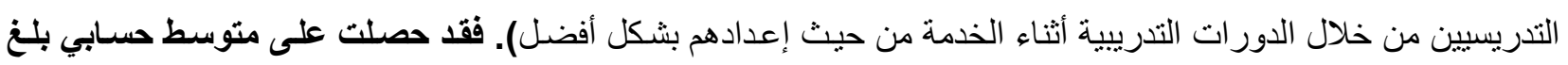

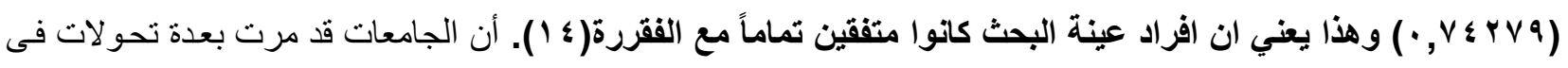

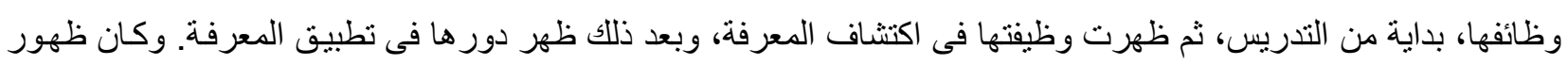

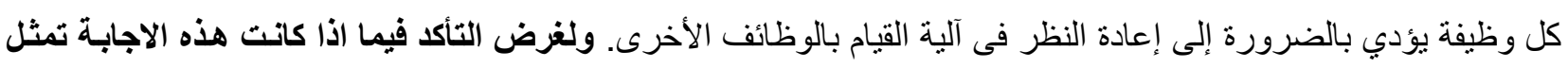

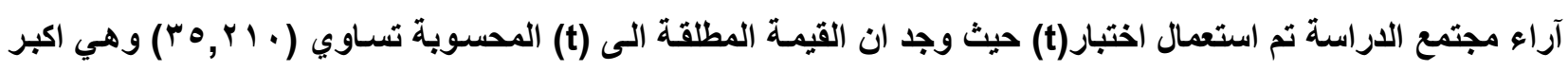

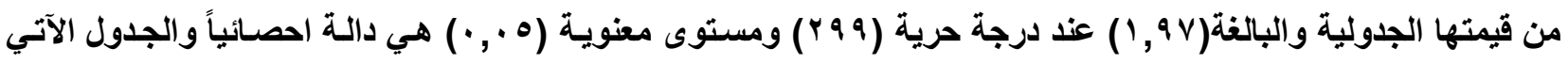

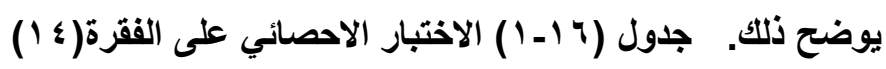

\begin{tabular}{|c|c|c|c|c|c|c|}
\hline \multicolumn{2}{|c|}{ درجة الثقة==9 \% } & \multirow{2}{*}{ المترسطات بين } & \multirow[t]{2}{*}{ معنوية الاختبار } & \multirow{2}{*}{ الحرية } & \multirow[t]{2}{*}{ اختبارt } & \multirow[t]{3}{*}{ ف عا } \\
\hline الحد الاعلى & الحد الادنى & & & & & \\
\hline $1,09 \leq \leq$ & $1,\{Y 04$ & $1,01 \ldots$ & $\cdot, \cdots$ & 199 & $r 0, r_{1}$. & \\
\hline
\end{tabular}

جدول (V ا ) الوسط الحسابي والانحر اف المعياري والخطأ المعياري لاجابات العينة على الفقرة(ه ( )

\begin{tabular}{|c|c|c|c|c|}
\hline الخطأ المعياري & الانحراف المعياري & الوسط الحسابي & عدد المفردات & 10 \\
\hline$\cdot, M r \cdot r$ & $\because, 00 \leqslant V$. & $\{, 7 \ldots$ & $\mu$ & \\
\hline
\end{tabular}

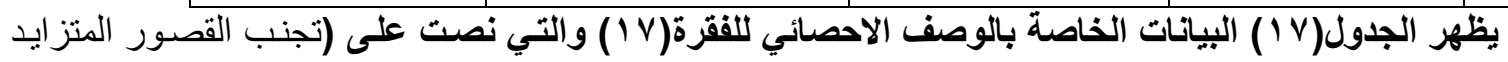

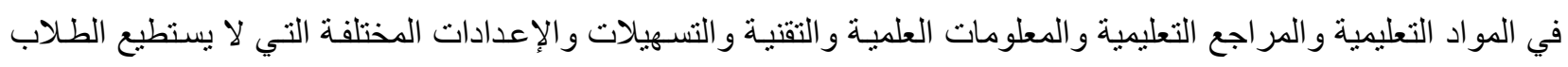

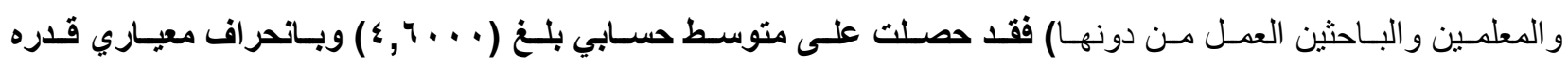

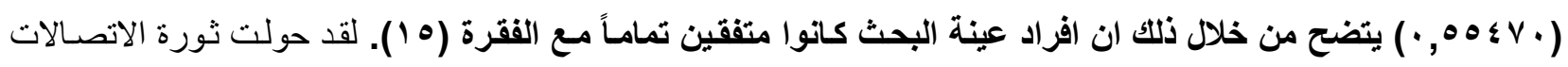

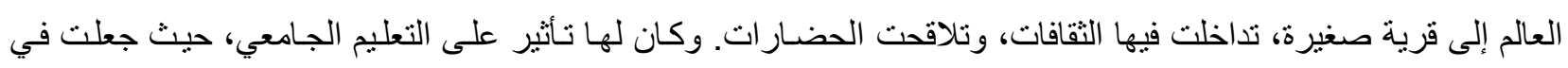

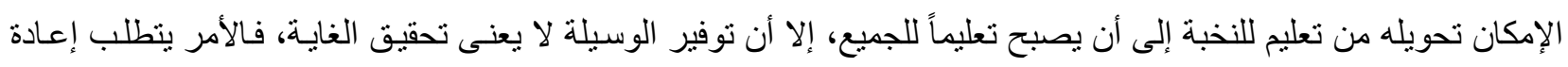

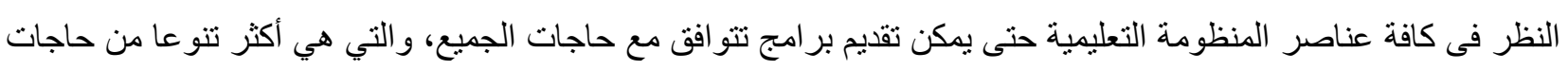

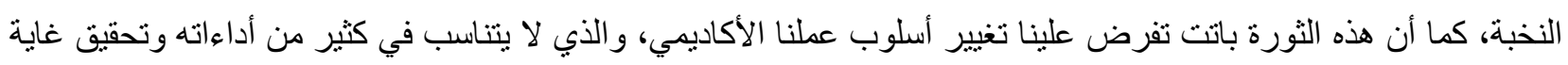


التعليم للجميع. ولغرض معرفة فيمـا اذا كانت هذه اجابـات تمثل آراء مجتمع الاراسـة تم استخدام اختبار(t) حيث وجد ان

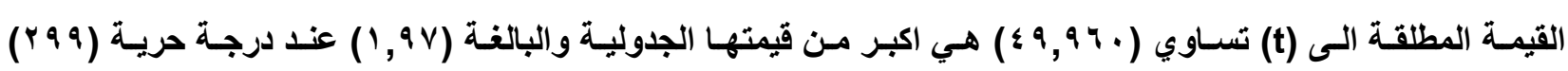
ومستوى معنوية (0 . . • ) هي دالة احصائياً والجدول الآتي يوضح ذلك.

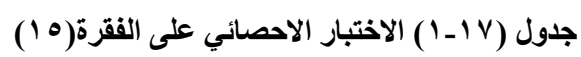

\begin{tabular}{|c|c|c|c|c|c|c|}
\hline \multicolumn{2}{|c|}{ درجة الثقة=9 \% } & \multirow{2}{*}{ المتوسط بين } & \multirow[t]{2}{*}{ معنوية الاختبار } & \multirow{2}{*}{ الحرية } & \multirow[t]{2}{*}{ اختبارt } & \multirow[t]{3}{*}{ ف 10} \\
\hline الحد الاعلى & الحد الادنى & & & & & \\
\hline $1,74 \pi$. & $1, \circ r v$. & $1,7 \ldots$ & $\cdot, \cdots$ & rqq & ะ9,94. & \\
\hline
\end{tabular}

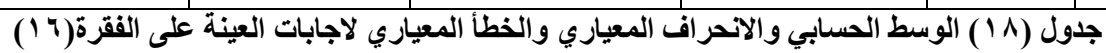

\begin{tabular}{|c|c|c|c|c|}
\hline الخطأ المعياري & الانحر اف المعياري & الوسط الحسابي & عدد المفردات & ف171 \\
\hline., $0.7 \varepsilon$ & $\cdot, \wedge \vee \vee I \mu$ & \&,YYTY & r.. & \\
\hline
\end{tabular}

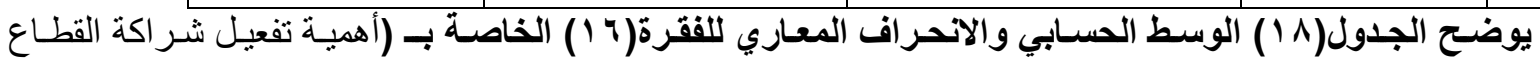

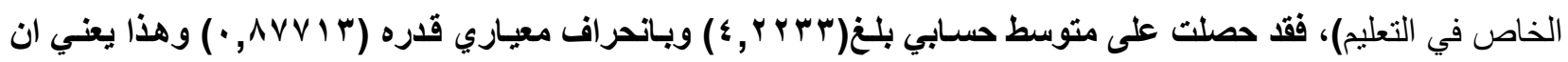

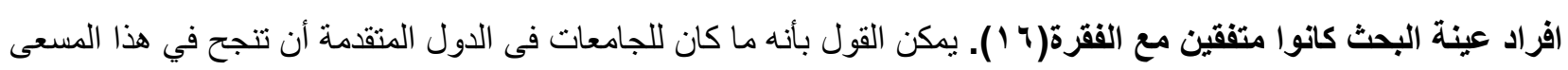

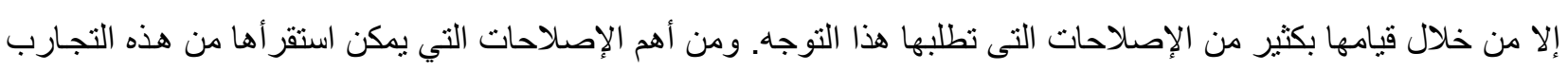

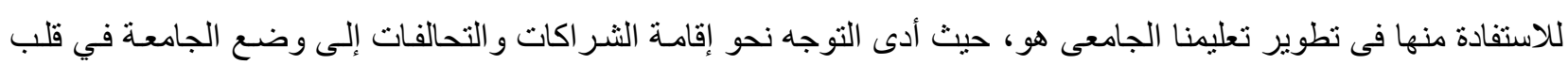

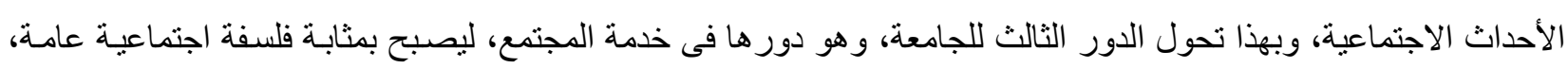

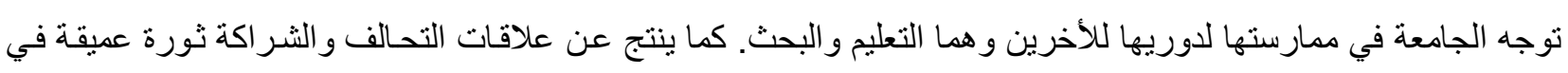

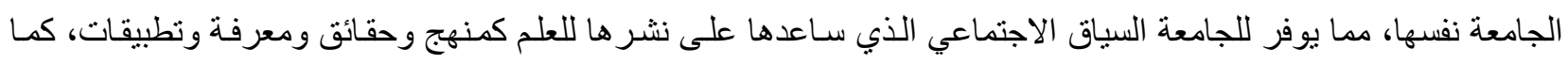
أفرز ذللك وعيا اجتماعيا بأهميـة العلم ودوره فى الحياة، وقد كان لتوافر هذا الوعي أثره الإيجابي على الجامعة والمجتمع. ولغرض التأكد فيما اذا كاتت هذه الاجابة تمثل آراء مجتمع الدراسة تم استعمال اختبار(t) حيث وجد ان القيمـة المطلقة الى لى

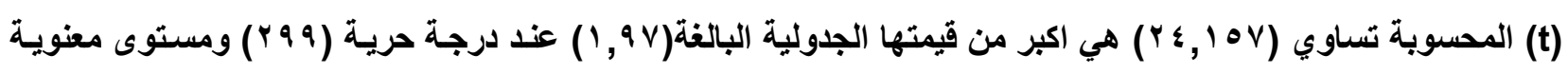
(0 • , · ) وهي دالة احصائياً والجدول الآتي يوضح ذلك.

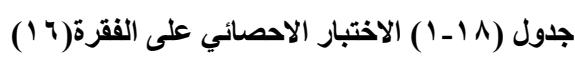

\begin{tabular}{|c|c|c|c|c|c|c|}
\hline \multicolumn{2}{|c|}{ درجة الثقة"=99\% } & \multirow{2}{*}{ المتوسطات } & \multirow[t]{2}{*}{ معنوية الاختبار } & \multirow{2}{*}{ الحرية } & \multirow[t]{2}{*}{ اختبارt } & \multirow[t]{3}{*}{ ف 14} \\
\hline الحد الاعلى & الحد الادنى & & & & & \\
\hline I, TrT. & $1, I Y T V$ & 1,YYYTY & $\cdot, \cdots$ & r99 & $r \leqslant, 10 V$ & \\
\hline
\end{tabular}

جدول (9 1 ) الوسط الحسابي والانحراف المعياري والخطأ المعياري لاجابات العينة على الفقرة(IV)

\begin{tabular}{|c|c|c|c|c|}
\hline الخطأ المعياري & الاتحراف المعياري & الوسط الحسابي & عدد المفردات & \multirow{2}{*}{ فVI } \\
\hline$\cdot, O Y \wedge 1$ & $\cdot, q 1 \leqslant V \leqslant$ & $\varepsilon, Y q \mu r$ & $r \ldots$ & \\
\hline
\end{tabular}

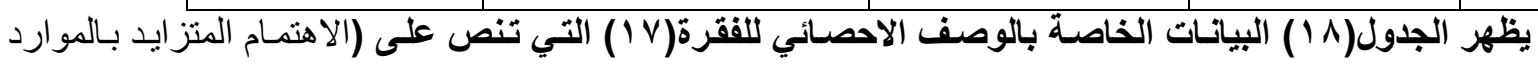

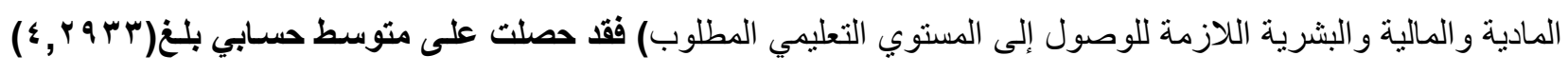

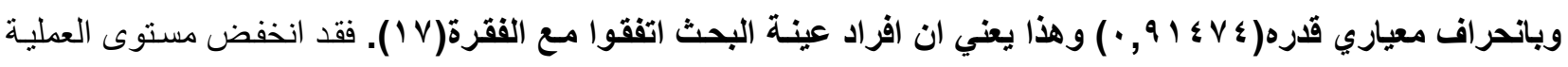


التعليمية في جامعاتتا، مما يستدعي ضرورة البحث عن سبل تحقيق جودتها. حيث هبطت وظيفة الجامعة من التفكير والتنظير

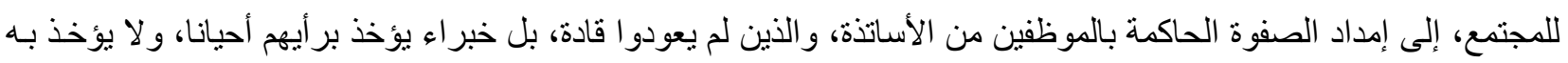
فى أحيان أخرى. ولغرض معرفة فيما اذا كاتت هذه الاجابة تمثل آراء مجتمع الدراسـة تم استخدام اختبار (t) حيث وجد ان

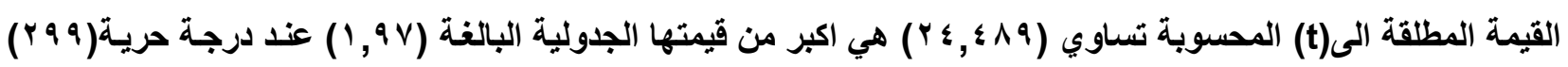
ومستوى معنوية (0 . . • ) وهي دلة احصائياً والجدول آتي يوضح ذلك. جدول (19 - 1) الاختبار الاحصائي على الفقرة( V V )

\begin{tabular}{|c|c|c|c|c|c|c|}
\hline \multicolumn{2}{|c|}{ درجة الثقة=099 } & \multirow{2}{*}{ الفرق بين المتوسطات } & \multirow{2}{*}{ الاختبار } & \multirow{2}{*}{ الحرية } & \multirow[t]{2}{*}{ اختبارt } & \multirow[t]{3}{*}{ ف ا } \\
\hline الحد الاعلى & الحد الادنى & & & & & \\
\hline $1, r q \vee r$ & $1,1 \wedge 9 \leq$ & 1, rqrrr &,$\cdots$ & rqq & $r \leqslant, \leqslant \wedge q$ & \\
\hline
\end{tabular}

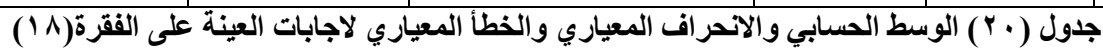

\begin{tabular}{|c|c|c|c|c|}
\hline الخطأ المعياري & الانحر اف المعياري & الوسط الحسابي & عدد المفردات & ف11 \\
\hline$\cdot, 7 \leq 1 Y$ & $1,11 \ldots 7$ & 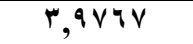 & $r \ldots$ & \\
\hline
\end{tabular}

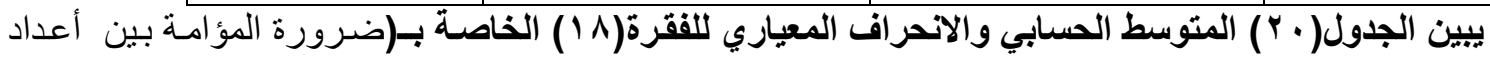
الأساتذة بما تناسب مع أعداد الطلاب، مما يحد كثير ا من قدرة الجامعات على الاستفادة من نظام الجودة بالثكل المأمول) فقد

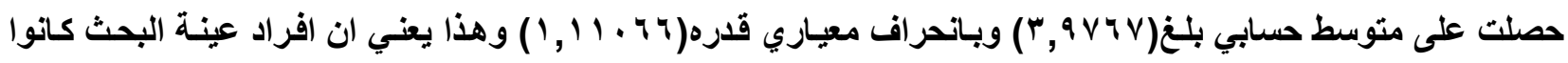

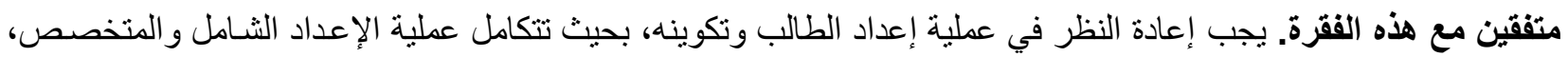
وذللك بتقديم معارف وتطبيقات ترتبط بمجموعة من التخصصات وبالتخصص الدقيق الذي اختاره الطالب. ولغرض التأكد فيما اذا كاتت هذه الاجابـة تمثل آراء مجتمع الدراسـة تم استخدان اختبار(t) حيث وجد ان القيمـة المطلقة الى(t) والمحسوية

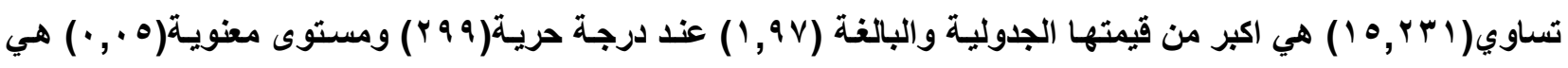
دالة احصائياً والجدول الاتي يوضح ذلتك.

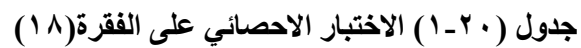

\begin{tabular}{|c|c|c|c|c|c|c|}
\hline \multicolumn{2}{|c|}{ درجة الثقة=09 \% } & \multirow{2}{*}{ المتوسطات بين } & \multirow[t]{2}{*}{ معنوية الاختبار } & \multirow{2}{*}{ الحرية } & \multirow[t]{2}{*}{ اختبارt } & \multirow[t]{3}{*}{ ف 1^| } \\
\hline الحد الاعلى & الحد الادنى & & & & & \\
\hline $1,1 \cdot r q$ & $\cdot, \wedge 0.0$ & 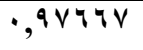 &,$\cdots$ & rq9 & $10, Y M 1$ & \\
\hline
\end{tabular}

جدول ( ا Y) الوسط الحسابي والانحر اف المعياري والخطأ المعياري لاجابات العينة على الفقرة(9 ( )

\begin{tabular}{|c|c|c|c|c|}
\hline الخطأ المعياري & الانحراف المعياري & الوسط الحسابي & عدد المفردات & ف919 \\
\hline$\cdot, \cdot \leq r \leq \Lambda$ & $\cdot,, \vee 0 Y \mid 1$ & $\varepsilon, r q r r$ & $r \ldots$ & \\
\hline
\end{tabular}

يوضح الجدول ( ا Y ) الوسط الحسابي والانحراف المعياري للفقرة(9 (1) الخاصة بـ(مدى قدرة الجامعة على توظيف الإمكانيات البشرية المتاحة كلا في تخصصه من اجل الإسهام في تحفيز العاملين ذوي العمل المتميز) فقد حصلت على مستوى لهن

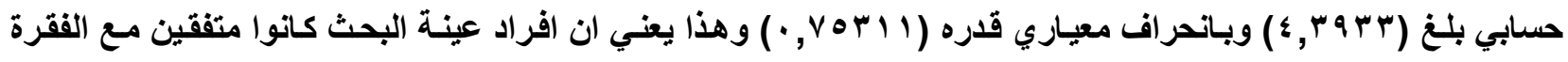

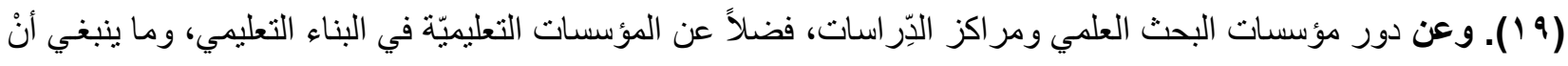

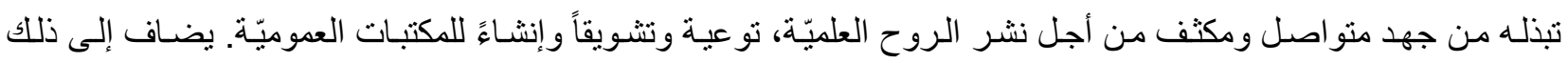
الاعتناء بالبحث العلمي نظر اً لما له من أهميّة كبرى وخطورة قصوى في البناء التعليمي، ويكون ذلك بالتشجيع عليه، ومد يد وليد 
المساعدة مادياً ومعنوياً للباحثين و الدارسين في مختلف الميادين المعرفيّة والعلميّة. وثَّـة أمر آخر بيـان دور مؤسسـات البحث

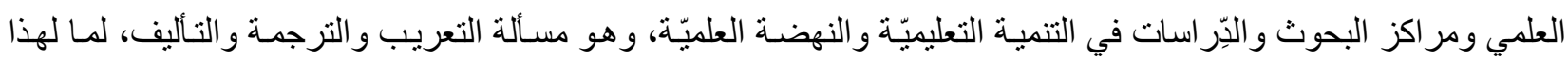
التنسيق من أثر فعّال ودور حيوي في البناء التعليمي وتثييد صرحه وتعليته. ولغرض التأكد فيما اذا كانت هذه الاجابات تمثنل آراء مجتمع الدراسة تم استخدام اختبار(t) حيث وجد ان القيمة المطلقة الى(t) المحسوية تساوي (0 ؛ ., بَّ) هي اكبر من

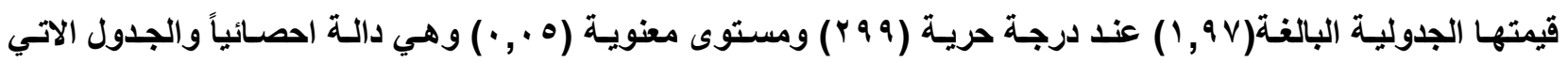
يوضح ذلك.

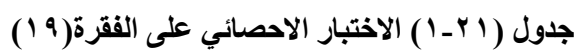

\begin{tabular}{|c|c|c|c|c|c|c|}
\hline \multicolumn{2}{|c|}{ درجة الثقة=09 \% } & \multirow{2}{*}{ المتوسطات بين } & \multirow[t]{2}{*}{ معنوية الاختبار } & \multirow{2}{*}{ الحرية } & \multirow[t]{2}{*}{ اختبارt } & \multirow[t]{3}{*}{ ف 19} \\
\hline الحد الاعلى & الحد الادنى & & & & & \\
\hline $1, \leqslant \vee \wedge 9$ & $1, r \cdot v \wedge$ & 1, & $\cdot, \cdots$ & rqq & $r r_{,} \leq 0$ & \\
\hline
\end{tabular}

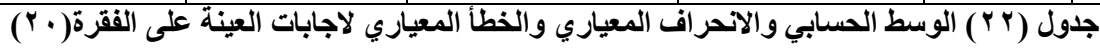

\begin{tabular}{|c|c|c|c|c|}
\hline الخطأ المعياري & الانحراف المعياري & الوسط الحسابي & عدد المفردات & ف.r \\
\hline$\cdot, \cdot \Delta \wedge \mid r$ & $1, \cdots 748$ & $\varepsilon, I \vee r \mu$ & $\mu$ & \\
\hline
\end{tabular}

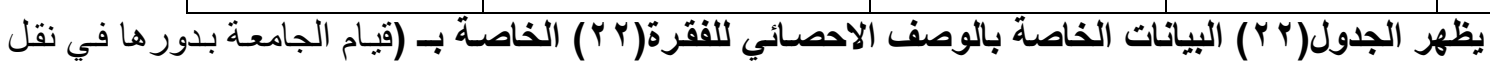

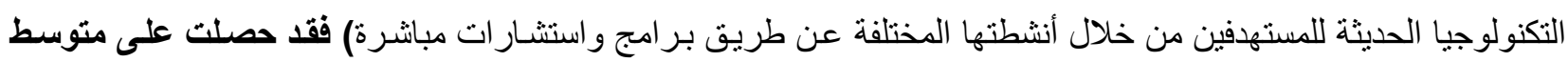

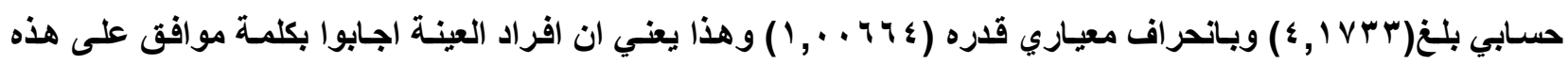

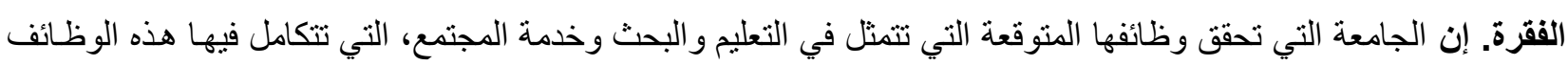

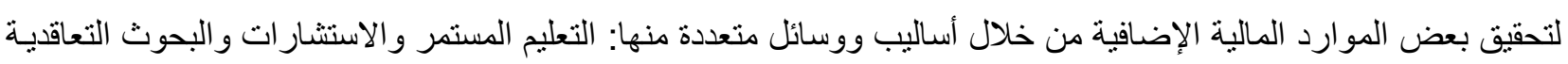
والأنشطة الإنتاجية. ولغرض معرفة فيما اذا كاتت هذه الاجابة تمثل آراء مجتمع الدراسة تم استخدام اختبار(t) حيث وجد ان

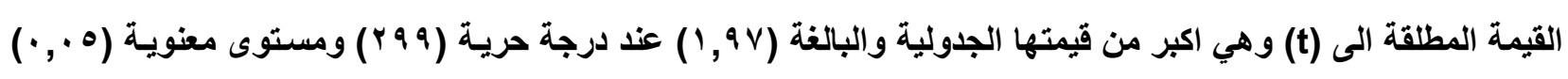
وهي دالة احصائياً والجدول الآتي يوضح ذلك.

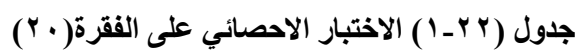

\begin{tabular}{|c|c|c|c|c|c|c|}
\hline \multicolumn{2}{|c|}{ درجة الثقة= 9 \% } & \multirow{2}{*}{ المتوسطات بين } & \multirow[t]{2}{*}{ معنوية الاختبار } & \multirow{2}{*}{ الحرية } & \multirow[t]{2}{*}{ اختبارt } & \multirow[t]{3}{*}{ ف •r } \\
\hline الحد الاعلى & الحد الادنى & & & & & \\
\hline $1, \leqslant \vee \wedge q$ & $1, .09$. & 1,IVHrr & $\cdot \cdots$ & rqq & $r \cdot, 1 \wedge q$ & \\
\hline
\end{tabular}

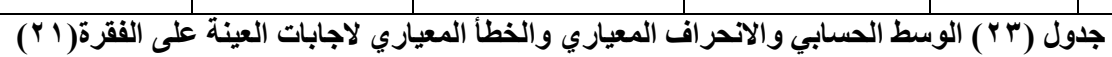

\begin{tabular}{|c|c|c|c|c|}
\hline الخطأ المعياري & الانحراف المعياري & الوسط الحسابي & عدد المفردات & فاب \\
\hline .,.०rqr &., $917 \vee r$ & $\varepsilon, \Psi_{\text {Y. }}$ & $r \ldots$ & \\
\hline
\end{tabular}

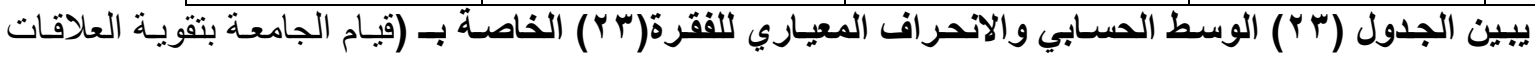

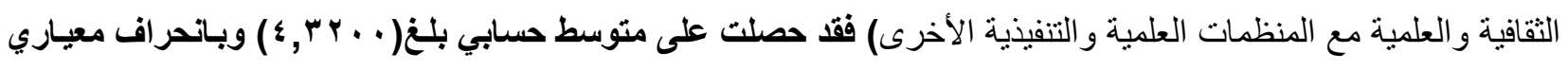

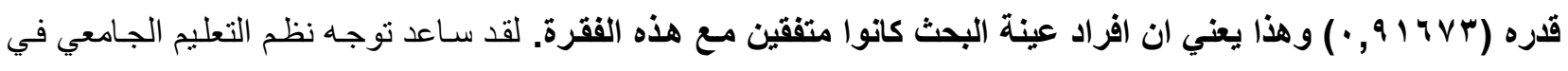

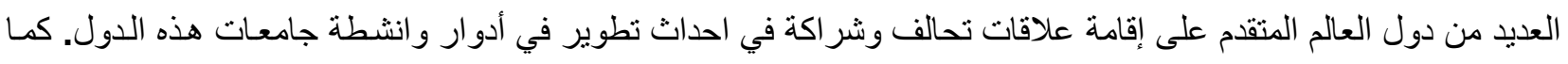

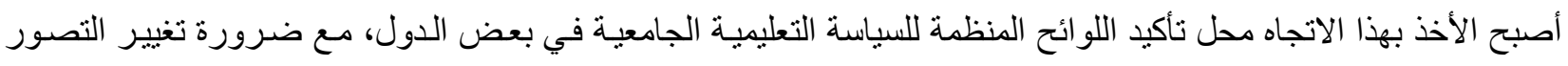


الذي يرى أن التطوير التكنولوجي يتبع خطا مستقيما يبدأ من البحث ثم يتجه إلى التطبيق، فالعلاقة يبين الطرفين أصبحت

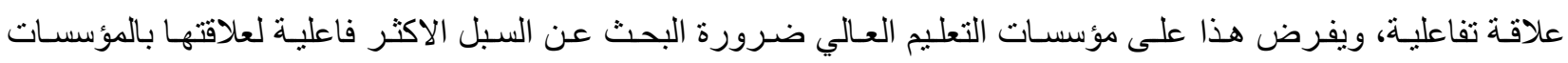
الصناعية و الخدمية والتجارية. ولغرض التأكد فيما اذا كاتت هذه الاجابة تمثل آراء مجتمع الاراسـة تم استعمال اختبار(t)

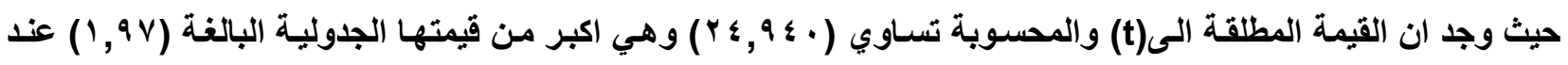

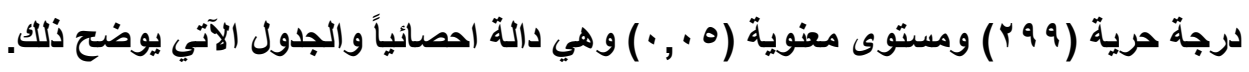

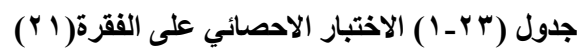

\begin{tabular}{|c|c|c|c|c|c|c|}
\hline \multicolumn{2}{|c|}{ درجة الثقة=09\% } & \multirow{2}{*}{ المتوسطات الفين } & \multirow[t]{2}{*}{ معنوية الاختبار } & \multirow{2}{*}{ الحرية } & \multirow[t]{2}{*}{ أختبارt } & \multirow[t]{3}{*}{ ف آץ } \\
\hline الحد الاعلى & الحد الادنى & & & & & \\
\hline $1, \varepsilon r \leqslant r$ & $1, r 101$ & $1, r r \ldots$ & $\cdot, \cdots$ & rq9 & $r \leq, q \leq$ & \\
\hline
\end{tabular}

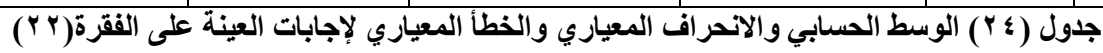

\begin{tabular}{|c|c|c|c|c|}
\hline الخطأ المعياري & الانحراف المعياري & الوسط الحسابي & عدد المفردات & فrr \\
\hline ., & •,OVTYT & $\varepsilon, 00 \ldots$ & $r \ldots$ & \\
\hline
\end{tabular}

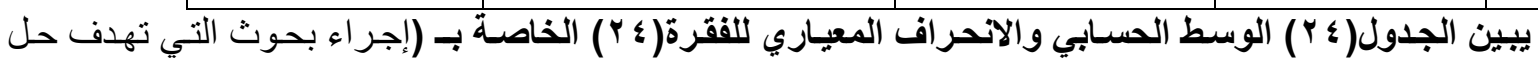

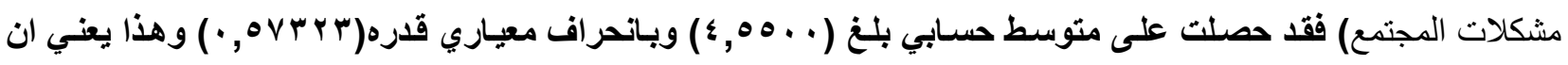

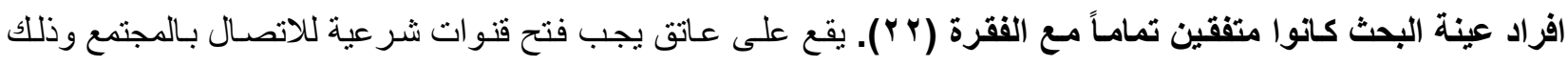

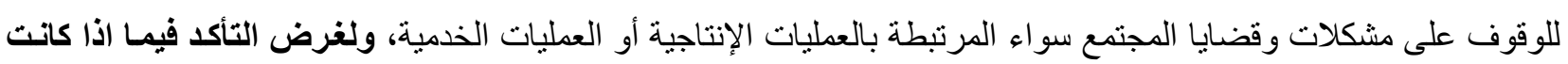

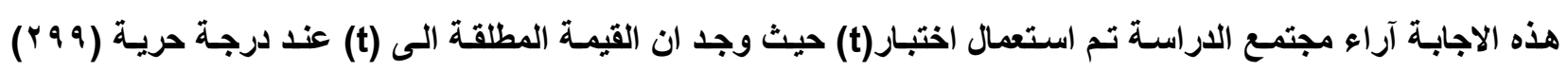
ومستوى معنوية(0) • • ) وهي دالة احصائياً والجدول الآتي يوضح ذلك.

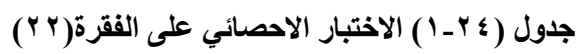

\begin{tabular}{|c|c|c|c|c|c|c|}
\hline \multicolumn{2}{|c|}{ درجة الثقة=0 9\% } & \multirow{2}{*}{ المتوسط بين } & \multirow[t]{2}{*}{ معنوية الاختبار } & \multirow{2}{*}{ الحرية } & \multirow[t]{2}{*}{ اختبارt } & \multirow[t]{3}{*}{ ف فYY } \\
\hline الحد الاعلى & الحد الادنى & & & & & \\
\hline 1,7101 & $1, \varepsilon \wedge \leqslant 9$ & $1,00 \ldots$ & $\cdot, \cdots$ & rqq & $\varepsilon \curlyvee, \wedge r \varepsilon$ & \\
\hline
\end{tabular}

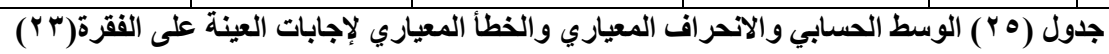

\begin{tabular}{|c|c|c|c|c|}
\hline الخطأ المعياري & الانحراف المعياري & الوسط الحسابي & عدد المفردات & فrץ \\
\hline$\cdot, .00 Y V$ & $\cdot, 9 \diamond \vee Y \wedge$ & $\varepsilon, \cdots$ & $\mu$ & \\
\hline
\end{tabular}

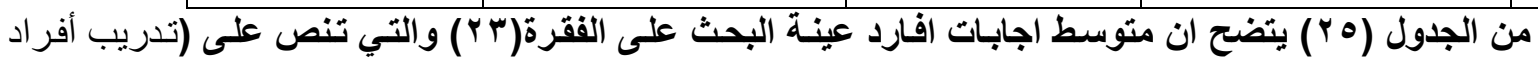

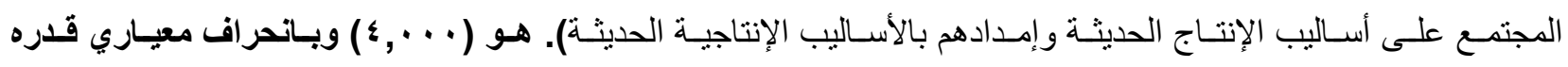

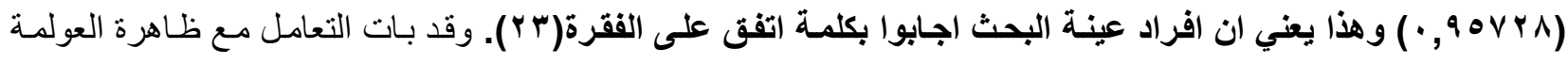

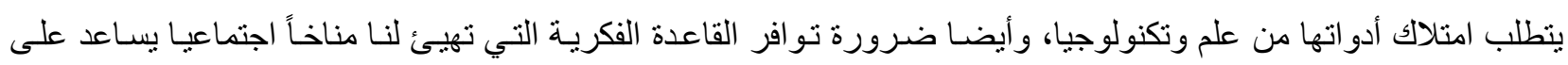

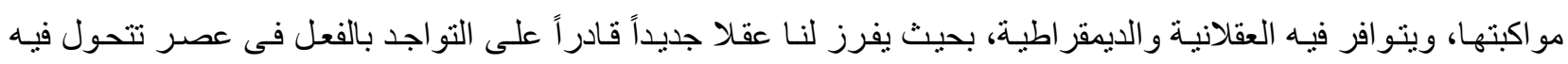

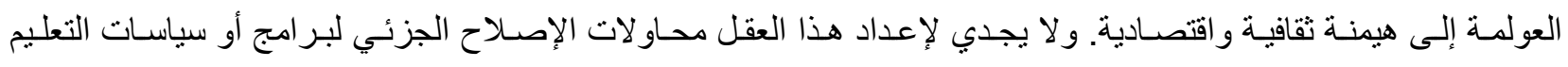

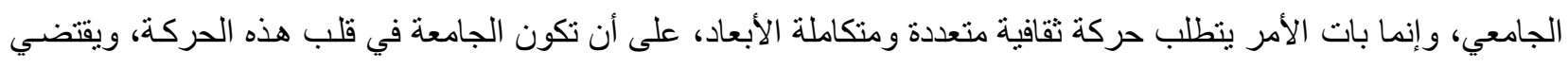

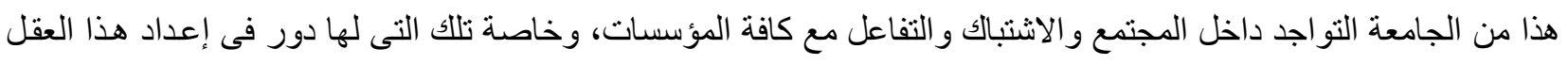


المنشود. ولغرض التأكد فيما اذا كاتت هذه الاجابة تمثل آراء مجتمع الاراسة تم استعمال اختبار(t) حيث وجد ان القيمة المطلقة الى(t)

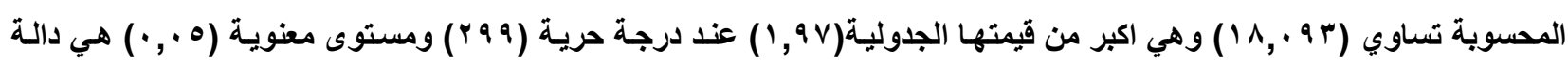
احصائياً والجدول الآتي يوضح ذلكاوي (الهـ

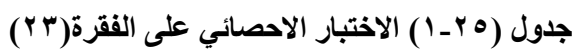

\begin{tabular}{|c|c|c|c|c|c|c|}
\hline \multicolumn{2}{|c|}{ درجة الثقة== 9 \% } & \multirow{2}{*}{ المتوسطات } & \multirow[t]{2}{*}{ معنوية الاختبار } & \multirow{2}{*}{ الحرية } & \multirow[t]{2}{*}{ اختبارt } & \multirow[t]{3}{*}{ ف } \\
\hline الحد الاعلى & الحد الادنى & & & & & \\
\hline $1,1 \cdot \wedge \wedge$ & $\cdot$, VVOY & $1, \cdots$ & $\cdot, \cdots$ & rqq & $11, \cdot 94$ & \\
\hline
\end{tabular}

التوصمبات:

ا - ضرورة تبني منهج دراسي يعتمد على إثارة إمكانات الإبداع والاستفسار و التحليل عند الطلاب وحثنه على الاستقلالية

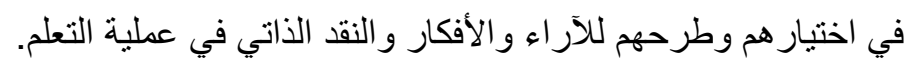
זـ تغيير أسس القبول بالجامعات و المعاهد وترجيح القدرات و الإمكانيات الثخصية مع ربط المقبولين في كل تخصص بحجم الطلب المتوقع في الفترات القادمة حتى يكون عدد الخريجين بالقدر الذي يحتاجه الاقتصاد. r- لابد ان يكون دور الدولة الرئيسي هو اصلاح التعليم العالي، في محاولة لجعل الجامعة عنصراً أساسياً للنمو الاقتصـادي

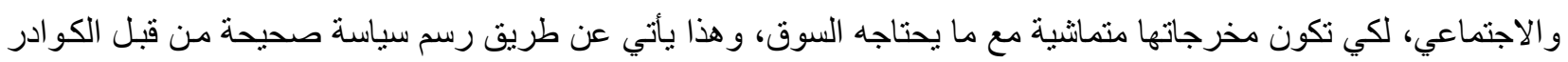

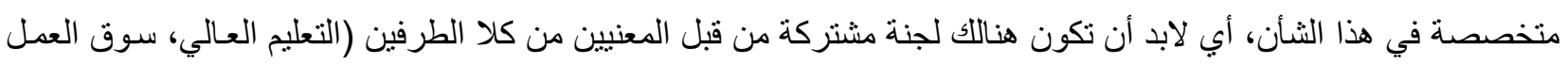

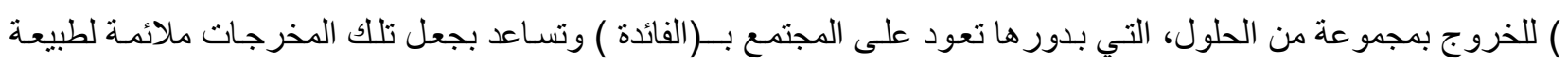
واحتياجات ذلك السوق. rـ إعداد وتطوير خطـة إستر اتيجية لضمان الجودة في الجامعـات العر اقيـة، وتقوم هذه الخطـة على توجيـه كافـة الأنشطة الأكاديمية و الإدارية والمالية نحو تحقيق رضاء العملاء و الأطراف ذات المصلحة مع التطوير والتحسين المستمر لجودة الخدمة

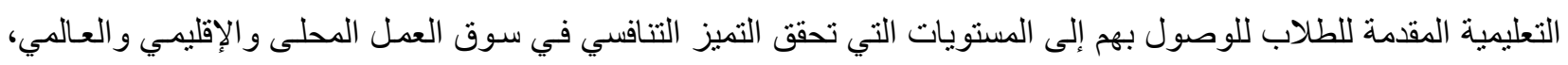

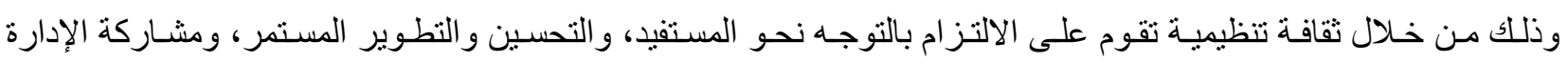
و العاملين في تحقيق الجودة والتميز في الأداء، مـع وضع نظسام لتقويم الأداء الجـامعي في كافـة جو انبها بمـا يحقق المعـايير الأكاديمية ومعايير الجودة الثاملة.

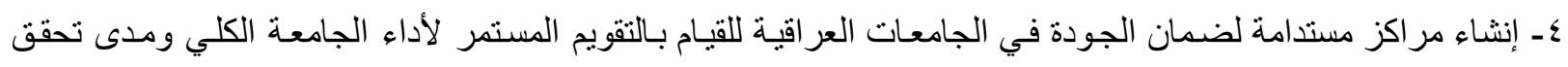
رسالته، إعداد التقارير الدورية عن أداء الجامعة واقتراح القرارات. هـ متابعة وحدات ضمان الجودة بالمؤسسات التابعة وتنسيق جهودها بما يضمن تبادل الخبرات، و إصدار التقرير السنوي

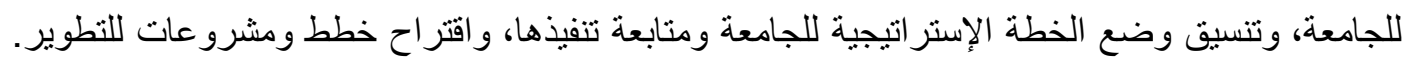
7ـ نشر ثقافة الجودة داخل الجامعة، وتفعيل المشاركة المجتمعية للمشاركة في الرقابـة ودعم نتائج الجودة، وبناء القدرات بين أعضاء هيئة التدريس و العاملين في مجال الجودة والمجالات الأخرى، ودعم عمليات التحسين المستمر لضمان الجودة الثاملة وتنسيق عملية إعداد الجامعة للتقدم للاعتماد. V- تتمية قدرات أعضاء هيئة التنريس و الجهاز الإداري في مجال الجودة. 


$$
\text { هـ ــ زيادة الموارد المخصصة على للتعليم والبحث العلمي مع الإيمان بأنهما من أهم الوسائل المؤدية لتقدم الأمم. }
$$

الخاتمةة

خلص البحث إلى أن جودة الأداء في التعليم تمثل إستر اتيجية هامة لتطوير المؤسسات التعليمية. وأن التجربـة العر اقية في تطبيق نظام الجودة قد تسهم بشكل فاعل في تطوير نظام التعليم إذا تم التعامل بشكل جدي وصحيح مع التحديات و المعوقات التي تحد من فاعليتها؛ مما سيكون له من مردود إيجابي واسع علي المجتمع كله. وحيث أن ثقافة الجودة وبر امجها تؤدى إلى اشتر الك كل فرد و إدارة ووحدة علمية وطالب و عضو هيئة تدريس ليصبح جزءاً من هذا البرنامج، وبالتالي فإن الجودة قد تمثل القوة الدافعة المطلوبة لدفع نظام التعليم الجـامعي بشكل فعـال ليحقق أهدافه ورسـالته المنوطـة بـه من قبـل المجتمع والأطر اف العديدة ذات الاهتمام بالتعليم الجامعي.

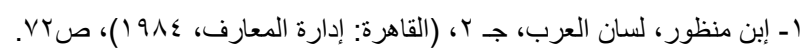

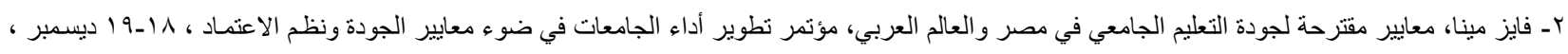

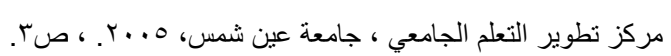

.Gibbs, G. (१९५). Improving The Quality of Student Learning, Technical \& Education Services L.T.D, U.K - ` ${ }^{\varepsilon}$ Castillo.Javier Alvarez Del, Evalution and Accreditation of Engineering Programmes in Latin America, Eurooean Journal of

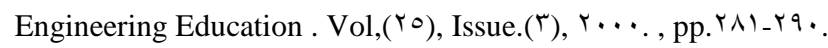

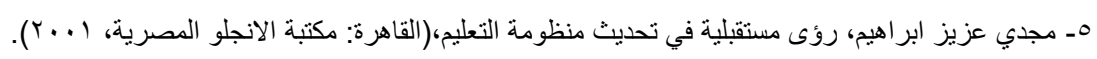

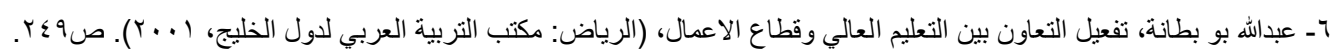

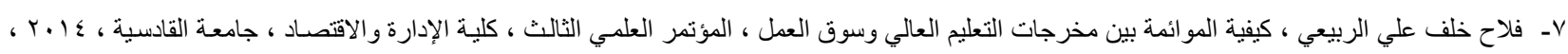
ص ص

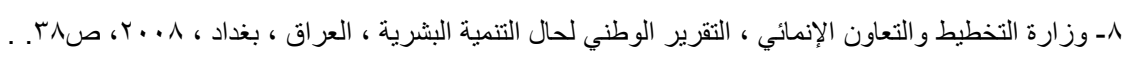

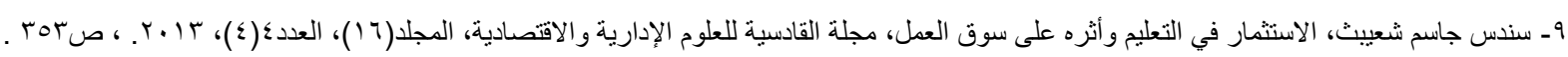

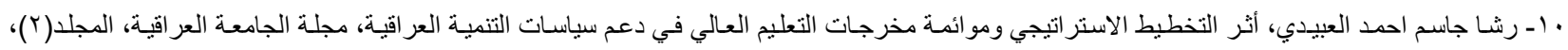

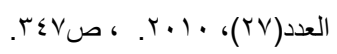
Ww.iasj.net 1)

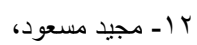
با إ حارث حازم أيوب، التتمية الاجتماعية في العراق المسارات و التحديات دراسة اجتماعية نحليلية، اطروحة دكتور اه غير منشورة ، كلية الآداب، جامعة بغداد

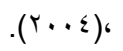

ـ ا - عبد الجليل الزوبعي ، مصدر سابق ، صبا.

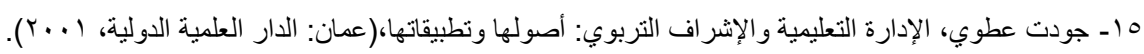

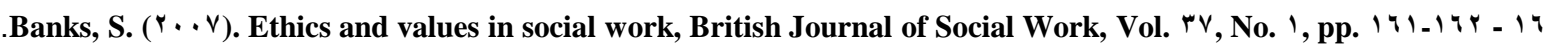

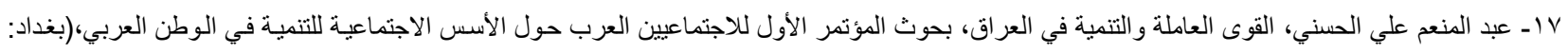

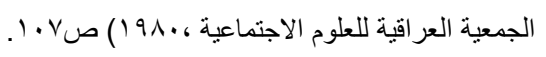

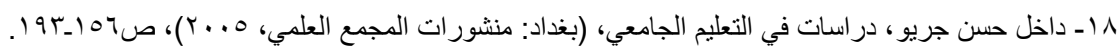

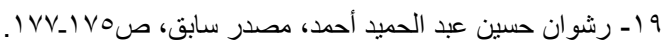

p. 19 ..Crosby, p. B. ( 19 १ ). Quality is free: the Art of Making Quality certain, New York: Mc Grew-Hill Book Co - Y.

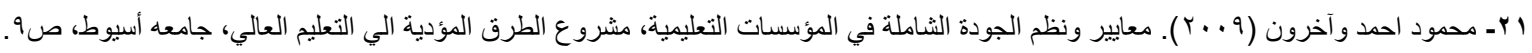

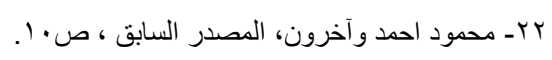

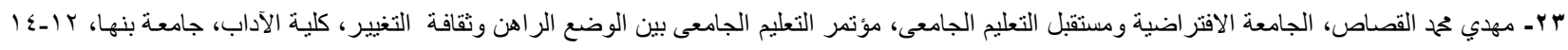

\section{$-V Y \varepsilon-$}

